\title{
HISTORICAL LEGACY AND POLICY EFFECTIVENESS: THE LONG-TERM INFLUENCE OF PREUNIFICATION BORDERS IN ITALY*
}

\author{
Giovanna d'Adda \\ Department of Management, Economics and Industrial Engineering (DIG), Politecnico di Milano, \\ Via Lambrischini 4b, Milan, Italy. E-mail: giovanna.dadda@polimi.it
}

\author{
Guido de Blasio \\ Department of Economics and Statistics, Bank of Italy, Via Nazionale 91, Rome, Italy. \\ E-mail: guido.deblasio@bancaditalia.it
}

\begin{abstract}
This paper investigates the interplay between cultural traditions and policy effectiveness. It explores the differential impact of a large development program (Cassa per il Mezzogiorno), implemented for four decades, starting in the 1950s, to stimulate convergence between Italy's south and the more developed north, on municipalities with different histories. Namely, we consider a sample of municipalities located on either side of the historical border of the Kingdom of the Two Sicilies, whose legacy is considered, from Putnam onwards, to be a prime-facie cause of Southern Italy's underdevelopment. Having been part of the Kingdom of the Two Sicilies is associated with a negative impact of development policies, but only when the allocation of development funds through the Cassa per il Mezzogiorno suffered from low quality of governance and was driven by political considerations rather than by efficiency ones.
\end{abstract}

\section{INTRODUCTION}

A large literature regards history as one of the main determinants of current economic development. This literature suggests that the slow-changing nature of cultural norms might explain the long-lasting effects of historical events. ${ }^{1}$ Historical institutions shape cultural beliefs and norms, which in turn are transmitted across generations and influence the selection, design and performance of current institutions (Guiso, Sapienza, and Zingales, 2008; Tabellini, 2008). A rather unexplored territory is the relation between current policy effectiveness and cultural norms. Do inherited cultural traits account for differences in the effectiveness of development policies? What triggers the influence of historical legacies? In particular, are certain policies less vulnerable to the cultural environment? This paper aims at addressing these questions.

Italy is an extraordinary laboratory to test the importance of cultural heritage: over the centuries different areas of the country experienced different political dominations, with related significant cultural diversities. Since 1861, however, there has been a unique State, with a single legal and political framework. Thus, economic agents with different cultural traditions might be observed in a similar environment. It is not surprising,

*We are grateful to Diego Gambetta, Carlo Menon, Tommaso Nannicini, Paolo Sestito, Guido Tabellini, participants at the European Regional Science Association (St. Petersburg, August 2014), the Italian Association of Labor Economics (Pisa, September 2014), and the Italian Economic Association (Trento, October 2014) for helpful comments. Giovanni Occhiali and Fabrizio Di Girolamo provided excellent research assistance. All errors remain our own. The views expressed herein are those of the authors and do not necessarily reflect the views of the institutions they are affiliated with.

Received: October 2015; revised: February 2016, May 2016; accepted: May 2016.

${ }^{1}$ See Nunn (2009) for a review. 
then, that a large literature has developed, exploiting the Italian context to study the interplay between cultural norms and policy change. Investigating the introduction of regional governments in Italy, Putnam, Leonardi, and Nanetti (1993) make the point that local traditions of civicness are the single most important determinant of the different performance of the newly designed institutions across regions. In the same vein, Giordano and Tommasino (2011) provide empirical evidence that Putnam et al.'s (1993) theory might be able to explain local public sector efficiency during the 2000 s. Bosker et al. (2008) highlight the importance of history and institutions on the spatial distribution of economic activity, focusing on the long standing differences between northern and southern Italy. On the other hand, policy interventions can in turn induce changes in norms and perceptions. This view is also supported by empirical evidence. Barone and Mocetti (2011) show that taxpayers are less prone to cheat on taxes, if they live in places where public services are efficiently provided. Barone and de Blasio (2013) document that a key civic virtue, voter participation, is spurred by transparent and accountable electoral systems. Accetturo, de Blasio, and Ricci (2014) provide evidence that EU transfers, namely structural funds targeted to underdeveloped regions, might have impacted negatively on the endowments of trust and cooperation of the receiving areas. ${ }^{2}$

This paper contributes to the debate on the interplay between cultural norms and policy effectiveness, by presenting evidence from Italy on the differential effect of a development program depending on its main characteristics and recipient areas' history. Relative to the existing literature, the original contribution of this paper is in highlighting that historical legacy may not necessarily have a persistent impact on development, provided that good policy designs and governance systems are in place. In the Italian case, this is the first paper that looks at the crucial interplay between the quality of policy-making and historical legacy (see Becker et al., 2015, for an empirical investigation referring to the Habsburg Empire). Two features of the location-based program studied here are critical for our analysis. First, the program covered a vast area that includes municipalities formerly belonging to different historical systems of government. Second, dramatic changes in the quality of governance and accountability occurred during the four decades of the program's duration. We can thus analyze whether inherited cultural traits affected the effectiveness of the program, as its governance system changed.

The policy we consider is the "Cassa per il Mezzoggiorno" (henceforth CasMez), a transfer program set up in 1950 by the Italian government, and born under the auspices of the World Bank, to foster the growth of the south. The program aimed to endow the Mezzogiorno with an adequate stock of infrastructure and promote the industrialization process, by directing private and public investment to the southern territories. On the implementation side, the program had two main phases (Battilani and Fauri, 2008): throughout the $1950 \mathrm{~s}$ and the $1960 \mathrm{~s}$, it was managed by a steering committee of experts, whose decisions were characterized by great autonomy from the political agenda. Legislative changes, fostering a more prominent influence of national and local politicians over the CasMez's decisions, ${ }^{3}$ resulted in deteriorating levels of governance and increasing rates of rent-seeking in funding allocation over the 1970s and 1980s (Cafiero, 2000). The distinction between these two phases (see, also, Felice and Lepore, 2013) is reflected also in the total cost of the program, which jumped from a total of almost 7.5 billion euros disbursed during the first phase to a total of more than 42.1 billion euros during the second one (Lepore, 2012a).

\footnotetext{
${ }^{2}$ For other relevant contributions on the impact of policy reform on social norms, see also Banerjee et al. (2012), and Beaman et al. (2009, 2012).

${ }^{3}$ Law 717/1965.
} 
In terms of historical legacies, we consider, following Putnam et al. (1993), the systems of government prevailing at the beginning of the 14th century as the most relevant in explaining contemporary differences in civicness. Putnam identifies four regimes prevailing at that time, corresponding to differing degrees of republicanism and autocracy: the Kingdom of the Two Sicilies (henceforth Kingdom) ${ }^{4}$, marked by the highest degree of autocracy, the Papal States, ${ }^{5}$ characterized by a mixture of feudalism, tyranny, and republicanism; the Signorie, former communal republics fallen prey to signorial rule by the beginning of the 14th century; and the Communes, the heartland of republicanism. This and other key contributions in the literature on history's influence on social capital levels in Italy (Guiso et al., 2008) lead us to view historical legacies as differences in cultural traits and norms of civicness.

The importance of inherited cultural traits for the effectiveness of a policy could be ideally measured through an experiment. The sample would include areas that are similar in terms of potential correlates of policy effectiveness-such as economic development, population size, geography, access to markets and infrastructures-but that differ in terms of inherited cultural traits and exposure to the policy. The analysis would then compare economic development in the aftermath of the policy across these different areas. Although based on observational data, the empirical strategy adopted in this study follows this logic. We compare the growth performance of municipalities similar on the basis of sociodemographic characteristics, but different in terms of cultural endowments-some were part of the Kingdom while others were not-and exposure to the policy-some received funds from CasMez while others did not. This empirical strategy allows us to address a series of questions: did the policy have any effect on development, regardless of inherited cultural traits? Do cultural endowments matter for growth, regardless of the policy implemented? And did the interplay between policy and culture influence these outcomes? The fact that the CasMez experienced two different implementation phases will allow us to measure the impact of cultural heritage under the different governance structures that characterized each phase.

The regions that were part of the Kingdom and the area under the influence of the CasMez overlap to a great extent. This represents a major obstacle for our empirical investigation. However, along the historical and policy borders, we are able to find both municipalities that were part of the Kingdom without being targeted by the development scheme, and municipalities that received CasMez's funding without having belonged to the Kingdom. Our identification strategy relies on these cities (they belong to the following six Italy's regions: Abruzzo, Campania, Lazio, Marche, Molise e Umbria). This choice has pros and cons. Geographically close municipalities are likely to be homogeneous in terms of local characteristics, such as access to markets, infrastructures, geography, that might confound identification. Moreover, restricting the sample to such municipalities is bound to minimize the risk of unobservable characteristics biasing our results. On the other hand, the proximity between the municipalities in our sample is likely to generate spillovers between cities located on opposite sides of the historical and policy borders, and therefore be a source of attenuation bias in our estimates. Such spillovers may occur, for instance, through socialization between individuals living in cities on opposite sides of the Kingdom's border, to the extent that social interactions modify individuals' set of values. By the same token, spatial externalities from the aid scheme may prevent us from finding an effect of the CasMez. For instance, the funding can be used to build

\footnotetext{
${ }^{4}$ Sicily and Naples were separate crowns in personal union under the same king. Our empirical exercise covers territories under the crown of Naples only.

${ }^{5}$ As suggested by a referee, the term Papal States is preferable to Papal State, as this political entity also includes territories that were acquired in the early-16th century. 
infrastructures (i.e., a road) that spur economic development also in neighboring places. Even more importantly, by focusing on the areas around the historical Kingdom and CasMez's borders, we can only compare municipalities formerly under the Kingdom with places formerly under the Papal States. Therefore, we can only contrast the two areas that in Putnam et al.'s (1993) taxonomy rank, respectively, last and second to last in terms of endowments of civicness. These considerations guide our empirical strategy, but also imply that our results are likely to represent a lower threshold of the effects we aim to capture in this study.

The main result of the paper is that cultural norms of uncivic behavior inherited from the past negatively affect policy effectiveness only in the second phase (1971-1991) of the CasMez. Over the first two decades (1951-1971), when the policy was characterized by centralism, autonomy and technical leadership, we fail to find any impact of Kingdom's legacy. Rather, the policy contributed to the growth of the local economies irrespective of the system of government prevailing in the fourteenth century. On the other hand, our estimates suggest that, during the second phase of the CasMez, municipalities receiving public money still experienced a larger increase in the number plants and employed workers than their unfunded counterparts. However, these gains were null or even reversed among municipalities formerly belonging to the Kingdom. These findings are corroborated by an extensive sensitivity analysis. We also provide evidence in support of the idea that the effect we find is likely to be a lower bound estimate of the overall influence of cultural traditions on policy effectiveness.

Our results bear important implications for the design of policies aimed at promoting local development. They suggest that only certain types of policies interact negatively with historical traditions of uncivic behavior. As for the role of history as determinant of the current local economic performance, our findings confirm its importance and longlasting influence: after two decades (1951-1971), during which the effect of culturally inherited norms of cooperation were muted, it re-emerged in the presence of bad policies (1971-1991).

The paper is structured as follows. Section 2 reviews the literature on the effect of historical institutions on current development, with a particular focus on studies about Italy. Section 3 documents the role of the CasMez over its four decades of activity. Section 4 presents the dataset and the empirical strategy. Section 5 documents the findings. Section 6 concludes.

\section{HISTORICAL LEGACY, CULTURAL NORMS, AND CURRENT DEVELOPMENT}

The literature on the impact of historical institutions on current development, through their influence on cultural norms and social capital, is vast. In a seminal contribution, already mentioned above, Putnam et al. (1993) offer evidence that historical legacy, through its impact on local culture, matters for the quality of institutions and current local development. By examining the introduction of regional governments and their widely different performance across Italy, Putnam et al. show how, in areas that experienced free city states in the Middle Ages, higher levels of civicness are found and local institutions perform better. On the contrary, areas where the presence of the authoritarian Kingdom of the Two Sicilies prevented the formation of civic associations and norms of cooperation still display lower social capital and worse institutional and economic performance today. De Blasio and Nuzzo (2010) test the plausibility of Putnam's story by studying some current individual economic outcomes, such as worker productivity, entrepreneurship, and female labor market participation. Guiso et al. (2008) also confirm Putnam et al.'s argument, and find that city-state experience in the Middle Ages is associated with higher 
levels of social capital today, also within northern Italy. Similarly, Di Liberto and Sideri (2015) find a significant correlation between historical institutions and current public administration efficiency. In a study on the evolution of city growth over a very long period (1300-1861), Bosker et al. (2008) document that institutions are a key factor in explaining Italy dualistic development path. Felice (2013) explains how past institutions determined differences in human and social capital, which in turn hampered growth in the south and led to a north-south divide in the actual functioning of those institutions (see, also, Felice, 2012; Felice and Vasta, 2015).

Theoretical models have been proposed to explain the persistence of historical institutions, through their effect on cultural norms. In the model of Guiso et al. (2008), social norms of cooperation and trust are based on culturally transmitted beliefs about others' trustworthiness and on real experiences of cooperation. Institutions influence social norms by determining the net benefits from cooperation. Tabellini (2008) considers a model in which culturally transmitted values enhance the probability of cooperation. Improvements in formal institutions, especially those concerned with law enforcement, are capable of crowding in generalized trust. This suggests a complementarity between the quality of formal institutions and societal norms of generalized trust and trustworthiness. The effect of institutional differences can persist over time, thanks to the transmission of social norms across generations (see Albanese, de Blasio, and Sestito, 2016, for empirical evidence on the case of Italy). Our results confirm these arguments, as we observe how bad policies can cause historical norms of uncivicness to re-emerge, even after long periods of dormancy.

Related to the literature on the effect of institutions on trust are studies demonstrating how pre-existing trust, or more generally culture, affects the functioning of institutions. Not all policies and institutions are equally affected by historically inherited cultural traits. Crucially, the quality of implemented policies appears to affect their vulnerability to cultural biases. Fisman and Miguel (2007), in a study on parking violations committed by diplomats stationed in New York, find that cultural origins matter in determining behavior in the absence of formal enforcement, but such an effect disappears very rapidly once enforcement is imposed. With immunity, diplomats from countries with high corruption committed more parking infractions than those from less corrupt countries, but infractions were reduced dramatically once immunity was removed. Similarly, Grosjean (2014) finds that the persistence of a culture of violence is negatively correlated with the quality of formal institutions. Cassar, d'Adda, and Grosjean (2013), in an experimental study conducted in different regions of Italy, show that individual norms of trust and cultural origin influence cooperation when the quality of enforcement institution is low, but not in the presence of strong and impartial institutions. Such heterogeneity is observed at an aggregate level and over a longer time frame in the present study as well: when policies are of good quality, inherited social norms and culture do not affect their effectiveness. However, their influence emerges when the quality of governance is low.

\section{THE CASSA PER IL MEZZOGIORNO AND ITS TWO PHASES}

The CasMez was a public body created by De Gasperi's government in 1950 to fund the industrialization of southern Italy and reduce the gap in economic development existing between the north and south of the country. The CasMez was founded under the impulse of a series of Italian economists, public managers and proponents of big push theories within the IBRD, with the goal of reproducing the experience of local development agencies, such as the Tennessee Valley Authority, promoted in the U.S. during the New Deal (Lepore, 2012b). The CasMez service area included eight regions: Abruzzo, Molise, 


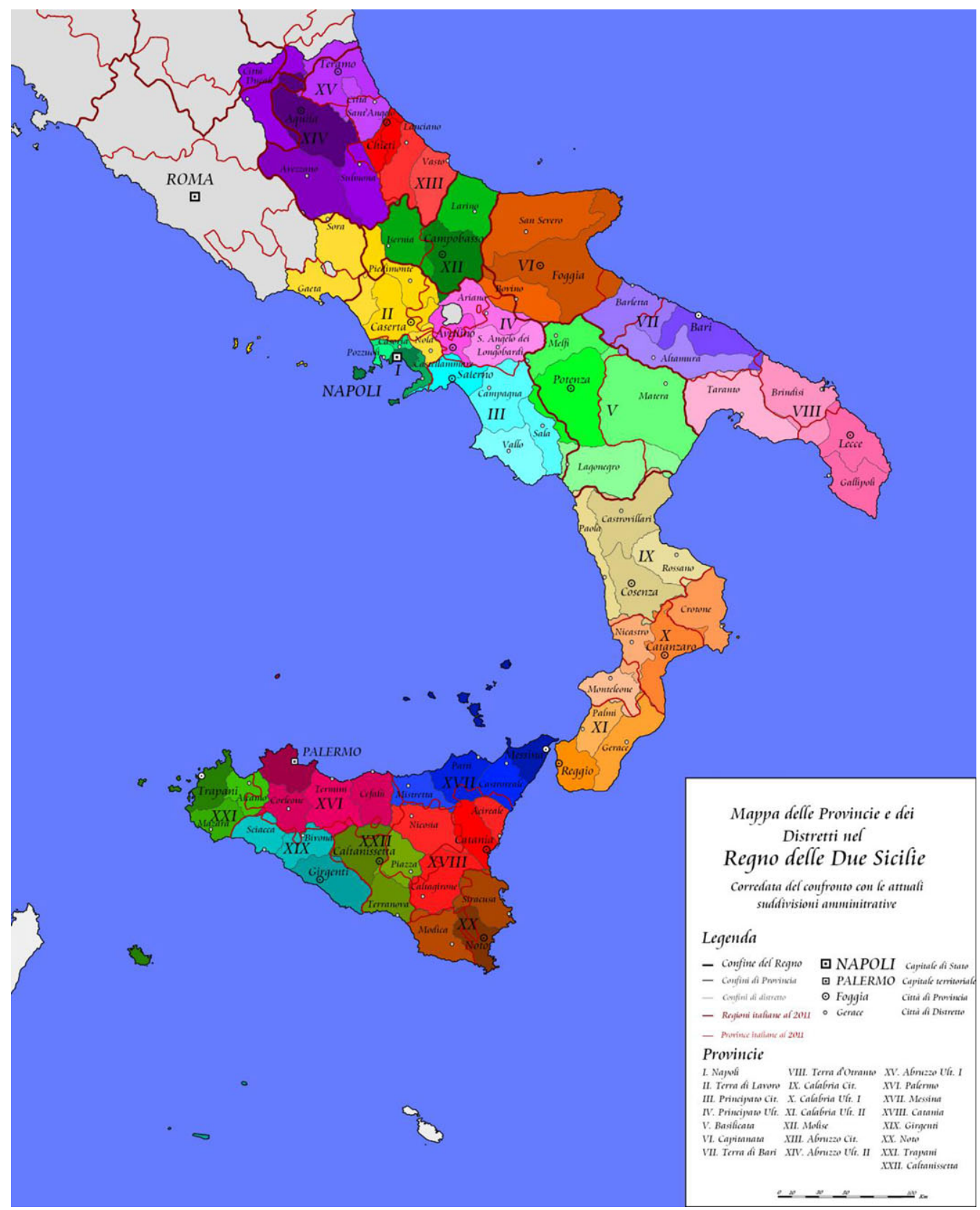

FIGURE 1: Kingdom's Border and Current Provinces' Boundaries.

Campania, Puglia, Basilicata, Calabria, Sicilia e Sardegna, the provinces of Latina e Frosinone in Lazio, the valley of the Tronto river, and a few minor islands off the coast of Tuscany. With the exception of some territories in Lazio and northern Abruzzo, this area largely coincides with the former Kingdom of the Two Sicilies. Figure 1 shows the former Kingdom's territory with respect to today's Italian provinces. 


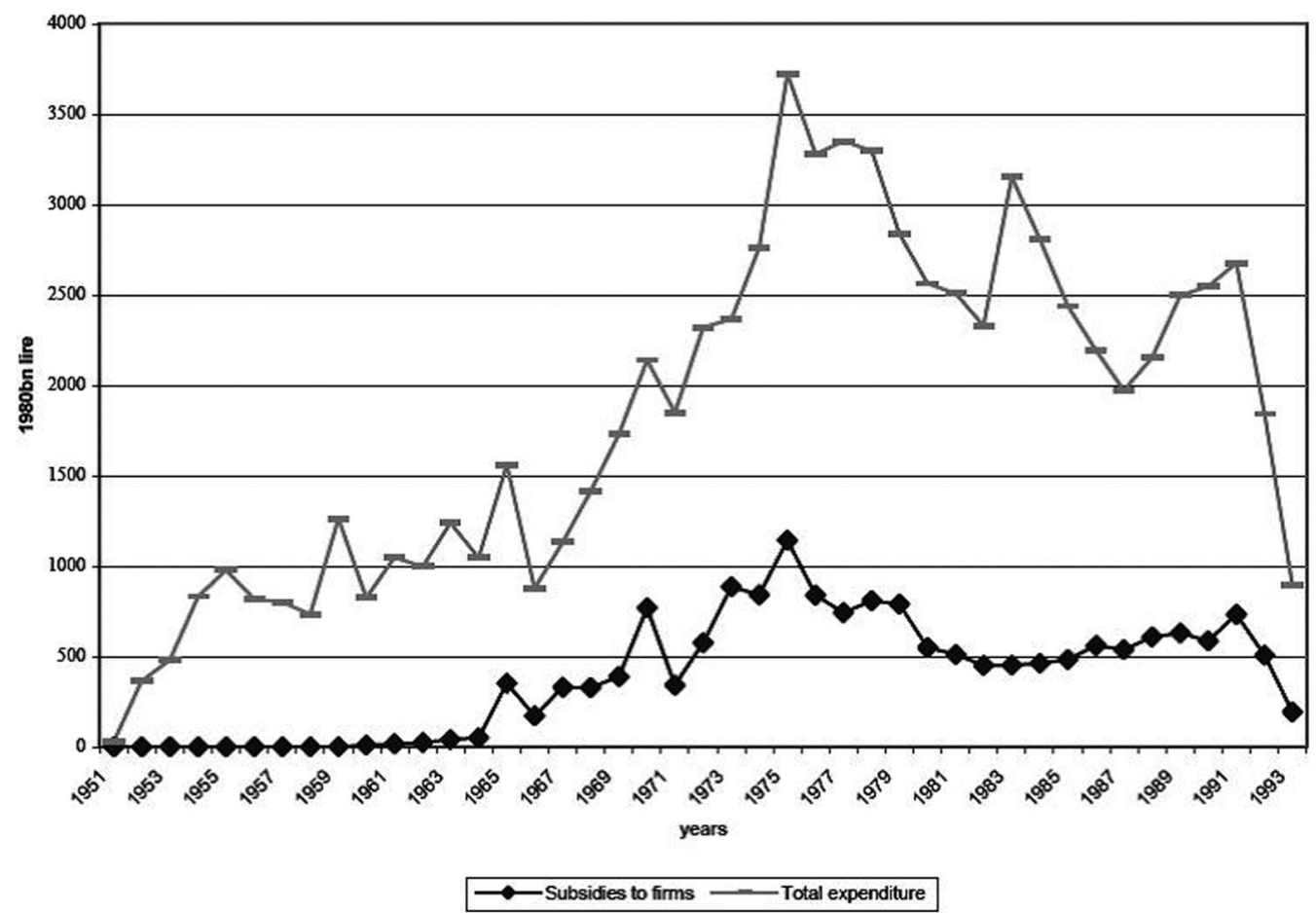

Source: A. Spadavecchia, Regional and National Industrial Policies in Italy, 1950s to 1993, Where Did the Subsidies Flow?, Reading, Henley Business School, University of Reading, 2007, p. 41; elaborated using CASMEZAGENSUD data (Bilanci della Cassa per il Mezzogiorno e dell'Agenzia per il Mezzogiorno, 1951-1993).

FIGURE 2: CasMez's Disbursements in Real Terms (1951-1993).

The CasMez, initially established for 10 years, was subsequently renewed multiple times, until it was replaced by another public body, the Agensud, in 1984, and definitely suppressed in 1992. Over these four decades, the CasMez directed to southern regions on average 4.593 billion euros per year (Lepore, 2012a). The transfers ranged between 0.5 percent, in the final years of the program, and 0.9 percent, in the $1970 \mathrm{~s}$, of the country's GDP. The value of tax subsidies must be added to that of the transfers. Tax subsidies to firms and households located in the south were introduced in the late-1960s, and were worth up to 1.3 percent of the GDP between 1976 and 1980. Figure 2 reports the trend in transfers and subsidies over the four decades of the CasMez.

In terms of use of the funds, the CasMez activity can be articulated into two stages (Felice, 2007; Felice and Lepore, 2013). During the first two decades of operations, at first pre-industrialization investments were targeted to the establishment of key infrastructure-roads, communication, water supplies-and to the requalification of vast swampy areas in southern Lazio, mainly favoring the agricultural sector (IBRD, 1953). Then this phase saw in the second decade an increasing role of projects aimed at fostering the development of industry in the south (Carlyle, 1962). The second stage, starting in the 1970 s, coincided with the inclusion of regional administrations in the decision process of funds' allocation. The regions favored a substitution away from investments for infrastructure and productive activities, and toward tax subsidies to support private consumption (SVIMEZ, 2001). The operations of the CasMez were increasingly characterized 
by a more volatile and fragmented allocation of the funds available to the agency during this phase (Bevilacqua, 1993; Viesti, 2003; Felice, 2007).

The distinction between these two stages of CasMez's operations also concerns the process with which the CasMez decided the funds' allocation, and the effectiveness of its action (Lepore, 2012b). The first two decades of the agency were characterized by the strong independence of the agency, led by a group of skilled administrators, from the political context. Indeed, the IBRD imposed as a condition for its support of the program that its implementation was delegated to a dedicated administrative body under the control of the IBRD itself, and independent from bureaucratic and political pressures (Felice, 2007). Starting from the 1970s, project selection and funds' allocation were increasingly captured by political interests and agents. The increasing influence of political actors on the CasMez's activity is captured by a law, requiring the CasMez's budgets to undergo scrutiny by the Government and giving the Government the power to dismantle the agency (Felice, 2007), introduced in the mid-1960s. These different actors and decision processes affected the effectiveness of the CasMez's action. The GDP gap between north and south declined between 1953 and 1973, suggesting, at least on the basis of pure correlation, the success of the policies promoted in the first phase, but the convergence process was reversed in the following decades (Daniele and Malanima, 2007; Felice, 2011; Felice and Vecchi, 2015).

\section{THE EMPIRICAL STRATEGY AND THE DATA}

In this paper we compare development outcomes, measured in terms of growth rates of plants, employment, and population, of similar municipalities, grouped on the basis of their exposure to the policy-municipalities that received funding from CasMez versus those that did not-and of their historically inherited cultural traits-municipalities that were part of the Kingdom versus those that were not. We consider only municipalities lying within a certain distance (50 or $100 \mathrm{~km}$, depending on the specification, see below) from the Kingdom's border, in order to limit the heterogeneity of municipalities in our sample. The fact that the areas targeted by the CasMez largely overlap with the former Kingdom's territories implies that these four groups of municipalities cover a limited portion of Italy's central and southern regions. However, we can exploit two sources of misalignment between the Kingdom and CasMez's areas of influence in our identification strategy.

The first one derives from the redefinition of administrative boundaries carried out during the Fascist regime (1922-1943). Figure 1 shows a map of the Kingdom's territory, with respect to today's provinces. Note that the border of the Kingdom cuts across five provinces of central Italy: Ascoli Piceno, Perugia, Rieti, Frosinone, and Latina, ${ }^{6}$ as some of the territories formerly part of the Kingdom were re-allocated to these provinces under the Fascist regime. The fact that the CasMez's area of influence was not strictly limited to the administrative provinces of the south of Italy provides a second source of misalignment. Besides the southern regions, the CasMez was targeted to a few additional underdeveloped areas: the provinces of Latina and Frosinone within the Lazio region, some municipalities in the provinces of Rome and Rieti, also within Lazio, of Ascoli Piceno, within Marche, and few Tuscan islands-Elba, Giglio, and Capraia.

Figure 3 shows in greater detail our sample of municipalities, grouping them on the basis of whether they fell within the boundaries of the CasMez and the Kingdom. The colored area represents the 639 municipalities lying within $50 \mathrm{~km}$ from the Kingdom's

\footnotetext{
${ }^{6}$ The map refers to the province borders as they were before the reform of the size of the provinces that was implemented in 2012. 


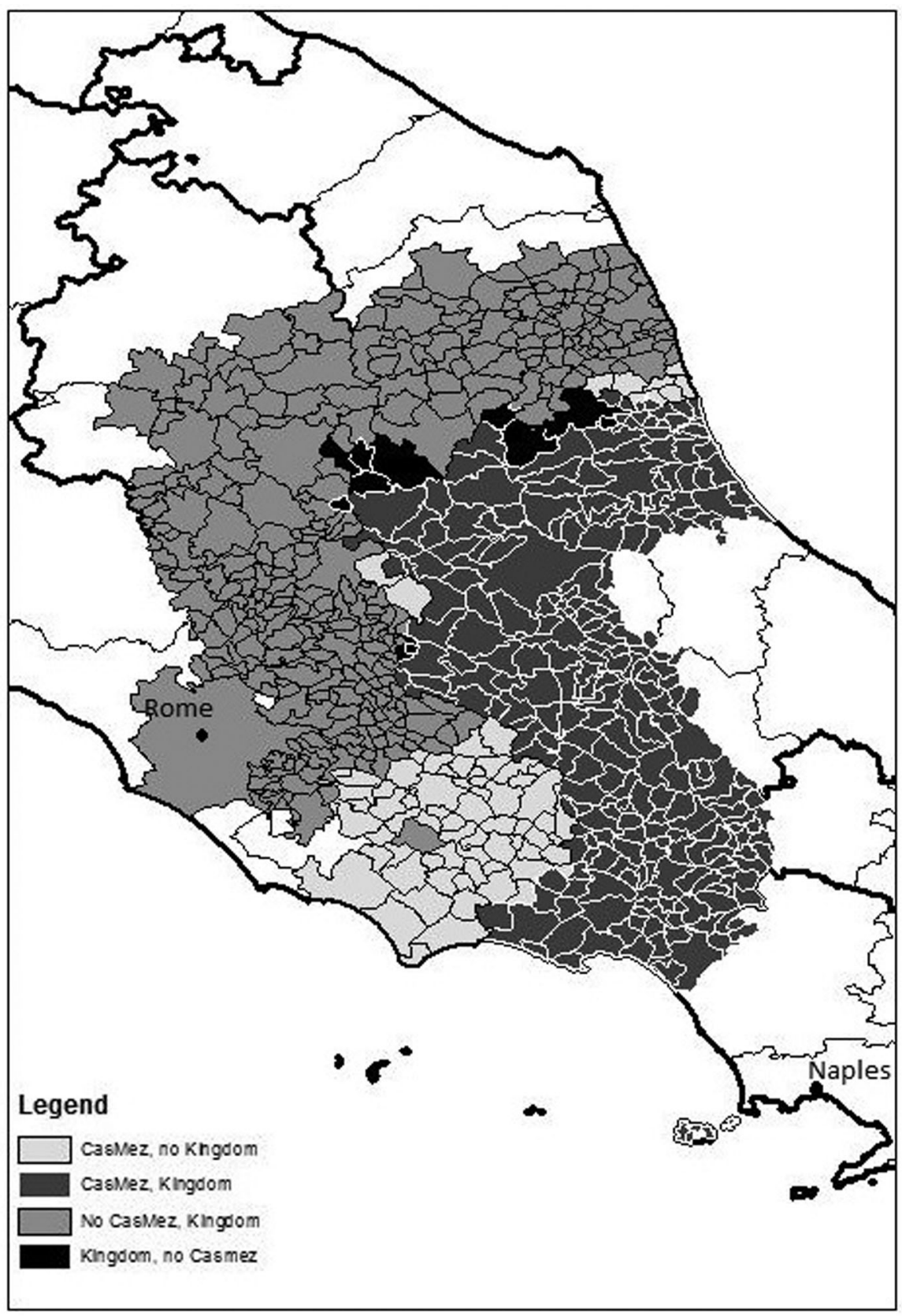

Source: Authors' elaborations. Legend: 1 . Dark gray-white borders: CasMez $=1$, Kingdom $=1$; 2 . Light grayblack borders: CasMez $=1$, Kingdom $=0 ; 3$. Dark gray-black borders: CasMez $=0$, Kingdom $=0 ; 4$. Black-white borders: CasMez $=0$, Kingdom $=1$.

FIGURE 3: Classes of Municipalities, Depending on History and Policy (50 km from Kindgom's Border). 
historical border on which our study focuses on. ${ }^{7}$ Among them, 252 used to be part of the Kingdom and received financial support from CasMez (dark gray, white borders), 304 lie at the north of the Kingdom's boundary and were not eligible for the financing (gray, black borders), 72 received funds from the CasMez without belonging to the Kingdom's former territory (light gray, black borders), and 11 did not receive any funds and were part of the Kingdom (black, white borders).

In terms of our identification strategy, we define two dummy variables, one equal to 1 if a municipality was targeted by the program, and the other equal to 1 if a municipality falls within the historical borders of the Kingdom. The four groups of municipalities in Figure 3 can thus be defined by the possible values taken by this pair of variables $(x$, $y)$. Type $(1,1)$ municipalities received CasMez's funding and formerly belonged to the Kingdom (dark gray, white borders in Figure 3). Type $(0,0)$ municipalities did not receive CasMez's funding and didn't belong to the Kingdom (gray, black borders in Figure 3). Type $(1,0)$ municipalities received funds from the CasMez without belonging to the Kingdom's former territory (light gray, black borders in Figure 3 ). Finally, type $(0,1)$ municipalities weren't targeted by the program and used to be part of the Kingdom (black, white borders in Figure 3).

The data for this study comes from a number of sources. Population, industry and services sectors census data, collected by the Italian Institute of Statistics (ISTAT) at the beginning of each decade, provide information at the municipal level on residing population, number of plants and related employment figures. Data on municipalities' geographic characteristics, such as altitude, size of the territory in squared kilometers, altitude range within the municipal territory, indicators for coastal cities or provincial capitals, are found in Italy's Association of Municipalities' (ANCI) archives. Italy's Association for the Development of the South (SVIMEZ) keeps administrative records with the list of municipalities receiving CasMez's support. Finally, we use GIS data to identify the municipalities belonging to the Kingdom, by overlaying the historical map of the Kingdom's borders (Figure 1) to contemporary maps of Italy. ${ }^{8}$ Appendix 1 in the online appendix presents the list of municipalities in our sample, and for each shows whether it received CasMez's support and was identified as lying within the Kingdom's border.

In the empirical analysis, we compare municipalities' growth performance, in terms of population, number of plants and employment, as a function of whether they received funding from CasMez, were formerly part of the Kingdom and of the interaction between policy and historical legacy. We perform this analysis for each of the two implementation phases of CasMez, to evaluate how the interplay between policy and inherited values plays out, depending on the quality of leadership and governance over funds' allocation. We run the following specification:

$$
\begin{aligned}
\mathrm{Y}_{\mathrm{ij} \mathrm{t}}= & \mathrm{a}_{0}+\mathrm{a}_{1} \text { CASMEZ }_{\mathrm{i}}+\mathrm{a}_{2} \text { KINGDOM }_{\mathrm{i}}+\mathrm{a}_{3}\left(\text { CASMEZ }_{\mathrm{i}} \times \text { KINGDOM }_{\mathrm{i}}\right) \\
& +\mathrm{a}_{4} \mathrm{X}_{\mathrm{ij} \mathrm{t}}+\mathrm{a}_{4} \mathrm{Z}_{\mathrm{ij}}+\mathrm{g}_{\mathrm{t}}+\mathrm{c}_{\mathrm{j}}+\mathrm{e}_{\mathrm{ij} \mathrm{t}},
\end{aligned}
$$

where $Y_{i j t}$ represents, depending on the regression, the growth rate, over each 20 -year CasMez's phase, in number of plants, employment or population in municipality $i$ belonging to province $j . C A S M E Z_{i}$ is the dummy variable taking value of one if the municipality receives funds from the program, while $K I N G D O M_{i}$ takes value of one if the municipality falls within the historical borders of the Kingdom. Our variable of interest is the interaction between these two indicators. Variable $X_{i j t}$ are time-variant controls, capturing

\footnotetext{
${ }^{7}$ The list of the municipalities is provided in the online appendix.

${ }^{8}$ Municipalities lying across the historical borders were assigned to the Kingdom if the majority of the municipal territory belonged to it.
} 
TABLE 1: Summary Statistics for 1951 Characteristics (50 km Bandwidth)

\begin{tabular}{|c|c|c|c|c|c|c|}
\hline & \multicolumn{3}{|c|}{ Full Sample (607 Municipalities) } & \multicolumn{3}{|c|}{ PS Sample (514 Municipalities) } \\
\hline & $\begin{array}{c}\text { CASMEZ }=1 \\
\text { (1) }\end{array}$ & $\begin{array}{c}\text { CASMEZ }=0 \\
\text { (2) }\end{array}$ & $\begin{array}{c}T \text { test } \\
(P \text {-value }) \\
(3)\end{array}$ & $\begin{array}{c}\text { CASMEZ }=1 \\
\text { (4) }\end{array}$ & $\begin{array}{c}\text { CASMEZ }=0 \\
(5)\end{array}$ & $\begin{array}{c}T \text { test } \\
(P \text {-value }) \\
(6)\end{array}$ \\
\hline Log Population & 8.815 & 9.058 & 0.55 & 8.950 & 9.015 & 0.83 \\
\hline Log Employment & 6.690 & 6.765 & 0.72 & 6.741 & 6.695 & 0.79 \\
\hline Log Plants & 5.393 & 7.945 & 0.05 & 5.421 & 5.943 & 0.45 \\
\hline Dummy for costal location & 0.75 & 0.42 & 0.08 & 0.63 & 0.59 & 0.61 \\
\hline Altitude & 402.76 & 421.80 & 0.51 & 405.31 & 415.15 & 0.79 \\
\hline Slope & 71.15 & 81.12 & 0.45 & 75.76 & 82.70 & 0.46 \\
\hline Surface $\left(\mathrm{km}^{2}\right)$ & 35.76 & 42.13 & 0.61 & 37.81 & 40.45 & 0.081 \\
\hline
\end{tabular}

Note: Data are from the 1951 Population Census, the 1951 Census on Industry and Services and the ANCI archives. The PS sample is selected through a propensity score routine based on the following variables: coastal town dummy, altitude, slope within the municipality, surface in $\mathrm{km}^{2}$, log of population and quadratic log of population in 1951, log of the number of plants and quadratic log of the number of plants in 1951, and log of employment and quadratic log of employment in 1951.

municipal population, number of plants, and employment at the start of decade, ${ }^{9}$ while $Z_{i j}$ are time-invariant controls, such as altitude, slope, location along the coast, and surface of the municipality. Finally, we include province-fixed ${ }^{10}$ effects, $\chi_{j}$, and time-fixed effects, since we estimate Equation (1) for two consecutive census periods.

In the empirical analysis, we will present results using two samples of municipalities. The first sample comprises all 607 municipalities falling within $50 \mathrm{~km}$ from the Kingdom's border, for which data are available for the four decades covered by our analysis. ${ }^{11}$ Within this sample, municipalities receiving CasMez's support are quite similar to those that did not get funded along many dimensions, as documented in Table 1. The table also shows, however, that some observable characteristics, such as the number of plants and the fact of being located on the coast, are significantly different across the two groups $(P=0.05$ and $P=0.08$, respectively). To make sure that our results are not driven by differences in observables, we test the robustness of our results to the use of a second sample, obtained using propensity score (PS) matching. We construct this sample using a routine that estimates the probability of a municipality being included in the CasMez area, given the following observable characteristics: being a coastal town, altitude, slope, surface, and pretreatment (1951) values of population, number of plants and employment. ${ }^{12}$ Using kernel matching, the PS routine retains only observations that share a common support. Within the resulting sample, which includes 514 observations, municipalities targeted by the program are similar along all pretreatment observable traits to those that were not targeted, according to standard $t$-tests shown in Table 1. Although we use all data available to construct this matched sample, we are aware of the scarcity of existing municipal-level data for the post-World War II period, and know that similarity along the available pretreatment observables does not guarantee our results are free from selection bias.

${ }^{9}$ These variables are also included in a quadratic form.

${ }^{10}$ This local jurisdiction corresponds to NUTS3 level.

${ }^{11}$ Out of the 639 municipalities lying within $50 \mathrm{~km}$ of the Kingdom's border (Figure 3), we drop 31 municipalities for which we have missing data over the four decades of our analysis. We also drop Rome from the sample, because of its size and role as national capital.

${ }^{12} \mathrm{As}$ in the main regressions, the latter three variables are also expressed as quadratic terms. 
On this, it is worth emphasizing that our empirical strategy controls for unobserved heterogeneity at the provincial level through province-fixed effects. However, unobserved heterogeneity across municipalities within the same province, in terms of potentially important determinants of growth such as human capital, research and development activity or infrastructure endowment, may affect our results, if such heterogeneity is observed at the level of former historical borders.

Another potential issue with our identification strategy concerns reverse causality. Our key argument is that the CasMez's change of governance system caused historical legacies to re-emerge. A similar relationship to the one we find would emerge if the municipalities characterized by worse historical legacies were the ones who became recipients of the CasMez or succeeded in determining the policy change between the first and the second phase of the CasMez. The presence of such reverse causality would determine an upward bias in our estimates. Concerning the first aspect, our identification strategy precisely relies on the fact that the CasMez area covered areas that both belonged and didn't belong to the Kingdom, and on the fact that the fund disbursement criteria in the first stage were exogenously imposed under the impulse of the IBRD. On the second aspect, while we cannot refute it, since we could not find a valid instrument for the CasMez and its change of governance, we do not find any support for it in the historical literature: in particular, Law 717/1965, which determined the change in governance between the first and the second stage of the CasMez, was driven by nationwide considerations, aimed at increasing the integration between central and local government bodies, rather than by local pressures on the legislator.

To address in the best possible way, given the scarcity of data, potential limitations of our empirical strategy, in what follows we perform an extensive series of robustness checks.

\section{RESULTS}

Table 2 reports results from Equation (1), using the full sample of municipalities within $50 \mathrm{~km}$ from the Kingdom's border.

The effect of historical legacy (KINGDOM), of being targeted by the policy (CASMEZ) and of their interaction $(\mathrm{CASMEZ} \times \mathrm{KINGDOM})$ is estimated for three different outcomes: the growth rates of plants, employment, and population. For each outcome, the table reports coefficients for the three regressors of interest under three specifications: in the first one, no additional controls, apart from a time dummy for the second census decade, are included; in the second specification we add all time-varying and time-invariant municipal level controls used for deriving the PS sample; in the third one, we also include province-fixed effects. This latter specification captures variations in outcomes variables among municipalities within the same province. Thus, adding local-fixed effects allows us to control for province-specific confounders, such as wage zones implemented up to 1971 (de Blasio and Poy, 2013), and, trivially, for potential confounders at the level of larger administrative jurisdictions, such as the regional governments introduced in 1975 (Putnam et al., 1993). The variables included in the different specifications additionally help us control for potential historical and cultural confounders: altitude, being correlated with the likelihood of a municipality being part of the Apennine area, allows us to control for cultural traits specific to mountainous areas; while province-fixed effects capture the influence of differences in history between provinces within the Kingdom or Papal States. We elaborate more on these points below.

Panel A shows the results from estimating Equation (1) for the period from 1951 to 1971 . This period represents the first phase of the program, when the financing was 
TABLE 2: The Effects of CASMEZ and KINGDOM on the Outcomes (Full Sample, $50 \mathrm{~km}$ Bandwidth)

\begin{tabular}{|c|c|c|c|c|c|c|c|c|c|}
\hline \multirow[b]{2}{*}{ Dep. Variables } & \multicolumn{3}{|c|}{ Growth Rate of Plants } & \multicolumn{3}{|c|}{ Growth Rate of Employment } & \multicolumn{3}{|c|}{ Growth Rate of Population } \\
\hline & (1) & (2) & (3) & (4) & (5) & (6) & (7) & (8) & (9) \\
\hline \multicolumn{10}{|c|}{ Panel A. 1951-1971 } \\
\hline CASMEZ & $\begin{array}{c}0.006 \\
(0.009)\end{array}$ & $\begin{array}{l}0.019^{\text {**** }} \\
(0.005)\end{array}$ & $\begin{array}{l}0.022^{\text {**** }} \\
(0.007)\end{array}$ & $\begin{array}{c}0.024^{*} \\
(0.013)\end{array}$ & $\begin{array}{l}0.052^{* * * *} \\
(0.007)\end{array}$ & $\begin{array}{l}0.047^{\text {***** }} \\
(0.009)\end{array}$ & $\begin{array}{c}0.005 \\
(0.012)\end{array}$ & $\begin{array}{l}0.004 \\
(0.007)\end{array}$ & $\begin{array}{r}0.002 \\
(0.009)\end{array}$ \\
\hline KINGDOM & $\begin{array}{c}0.013 \\
(0.015)\end{array}$ & $\begin{array}{c}0.011 \\
(0.012)\end{array}$ & $\begin{array}{c}0.015 \\
(0.013)\end{array}$ & $\begin{array}{l}0.009 \\
(0.018)\end{array}$ & $\begin{array}{c}0.013 \\
(0.013)\end{array}$ & $\begin{array}{c}0.011 \\
(0.010)\end{array}$ & $\begin{array}{c}0.003 \\
(0.025)\end{array}$ & $\begin{array}{l}0.009 \\
(0.016)\end{array}$ & $\begin{array}{r}0.007 \\
(0.019)\end{array}$ \\
\hline $\begin{array}{l}\text { CASMEZ } \times \\
\text { KINGDOM }\end{array}$ & $\begin{array}{c}0.005 \\
(0.022)\end{array}$ & $\begin{array}{c}0.009 \\
(0.015)\end{array}$ & $\begin{array}{c}0.008 \\
(0.016)\end{array}$ & $\begin{array}{l}0.006 \\
(0.020)\end{array}$ & $\begin{array}{c}0.012 \\
(0.015)\end{array}$ & $\begin{array}{c}0.008 \\
(0.012)\end{array}$ & $\begin{array}{c}0.007 \\
(0.031)\end{array}$ & $\begin{array}{l}0.003 \\
(0.017)\end{array}$ & $\begin{array}{r}0.002 \\
(0.020)\end{array}$ \\
\hline $\begin{array}{l}\text { Number of obs. } \\
R^{2}\end{array}$ & $\begin{array}{c}607 \\
0.045\end{array}$ & $\begin{array}{c}607 \\
0.145\end{array}$ & $\begin{array}{c}607 \\
0.166\end{array}$ & $\begin{array}{l}607 \\
0.052\end{array}$ & $\begin{array}{c}607 \\
0.178\end{array}$ & $\begin{array}{c}607 \\
0.198\end{array}$ & $\begin{array}{c}607 \\
0.009\end{array}$ & $\begin{array}{c}607 \\
0.142\end{array}$ & $\begin{array}{c}607 \\
0.144\end{array}$ \\
\hline \multicolumn{10}{|c|}{ Panel B. 1971-1991 } \\
\hline CASMEZ & $\begin{array}{c}0.007 \\
(0.007)\end{array}$ & $\begin{array}{c}0.011^{*} \\
(0.005)\end{array}$ & $\begin{array}{l}0.013^{* * *} \\
(0.005)\end{array}$ & $\begin{array}{c}0.005 \\
(0.012)\end{array}$ & $\begin{array}{c}0.009 \\
(0.006)\end{array}$ & $\begin{array}{l}0.010^{*} \\
(0.005)\end{array}$ & $\begin{array}{c}0.005 \\
(0.023)\end{array}$ & $\begin{array}{c}0.007 \\
(0.009)\end{array}$ & $\begin{array}{r}0.009 \\
(0.009\end{array}$ \\
\hline KINGDOM & $\begin{array}{c}0.001 \\
(0.013)\end{array}$ & $\begin{array}{c}-0.007 \\
(0.010)\end{array}$ & $\begin{array}{r}-0.008 \\
(0.011)\end{array}$ & $\begin{array}{r}-0.015 \\
(0.012)\end{array}$ & $\begin{array}{c}-0.011 \\
(0.012)\end{array}$ & $\begin{array}{c}-0.015 \\
(0.012)\end{array}$ & $\begin{array}{c}0.003 \\
(0.015)\end{array}$ & $\begin{array}{c}0.004 \\
(0.011)\end{array}$ & $\begin{array}{r}0.005 \\
(0.015)\end{array}$ \\
\hline $\begin{array}{l}\text { CASMEZ } \times \\
\text { KINGDOM }\end{array}$ & $\begin{array}{c}0.009 \\
(0.025)\end{array}$ & $\begin{array}{c}-0.039^{* *} \\
(0.015)\end{array}$ & $\begin{array}{c}-0.045^{\text {**** }} \\
(0.015)\end{array}$ & $\begin{array}{c}-0.019 \\
(0.022)\end{array}$ & $\begin{array}{c}-0.052^{\text {****** }} \\
(0.014)\end{array}$ & $\begin{array}{c}-0.051^{\text {**** }} \\
(0.016)\end{array}$ & $\begin{array}{c}0.009 \\
(0.025)\end{array}$ & $\begin{array}{l}0.004 \\
(0.013)\end{array}$ & $\begin{array}{r}0.004 \\
(0.015)\end{array}$ \\
\hline Number of obs. & 607 & 607 & 607 & 607 & 607 & 607 & 607 & 607 & 607 \\
\hline$R^{2}$ & 0.009 & 0.165 & 0.171 & 0.027 & 0.154 & 0.199 & 0.045 & 0.134 & 0.139 \\
\hline Controls & No & Yes & Yes & No & Yes & Yes & No & Yes & Yes \\
\hline $\begin{array}{l}\text { Province-fixed } \\
\text { effects }\end{array}$ & No & No & Yes & No & No & Yes & No & No & Yes \\
\hline
\end{tabular}

Note: OLS regressions, standard error in parentheses estimated based on Conley (1999), with a bandwidth of $50 \mathrm{~km}$. Observations include municipalities within $50 \mathrm{~km}$ from the KINGDOM boundary. Controls include coastal town dummy, altitude, slope within the municipality, surface in $\mathrm{km}^{2}$, log of population and quadratic log of population in 1951, log of the number of plants and quadratic log of the number of plants in 1951, and log of employment and quadratic log of employment in 1951.

*Significant at 10 percent; ** significant at 5 percent; ${ }^{* * *}$ significant at 1 percent.

centrally administered by a high-level steering committee shielded from vested interests. The results document that municipalities targeted by the CasMez program experienced better economic performance, captured by higher levels of growth in the number of plants and employment. While municipalities in the control group, that is those within $50 \mathrm{~km}$ from the Kingdom's border that didn't receive CasMez's support nor were formerly part of the Kingdom, experienced a cumulative growth rate of 15 percent in the number of plants and 42 percent in employment between 1951 and 1971, those targeted by the program grew approximately 2 and 5 percentage points faster in terms of these two outcomes, respectively. For both dependent variables the effect is smaller in the specification without controls (Columns 1 and 4, respectively). This illustrates the importance of controlling for pretreatment municipal characteristics. ${ }^{13}$ We fail to find any positive effect of the CasMez on the population growth rate. Crucially, the effect of the KINGDOM variable is never significant, nor is that of the interaction term CASMEZ $\times$ KINGDOM. These findings

\footnotetext{
${ }^{13}$ We replicate all our estimates by adding as additional controls both population density and average plant size. The results are barely distinguishable from those obtained with specifications that do not control for these two variables.
} 
suggest that the historical legacy of the Kingdom had no influence on municipalities' economic performance during the first implementation phase of the program.

Panel B presents the results for the period from 1971 to 1991. This period corresponds to the second implementation phase of the CasMez, when national and local politicians gained a leading role in the management of the funds and disbursement levels soared. In terms of growth rate of plants and employment, the effect of the CasMez is still positive, though smaller than in the previous phase and sometimes not significantly different from zero at the conventional levels. The dummy KINGDOM never enters significantly in the regressions, while, interestingly, the interaction between CasMez and Kingdom presents a negative and very significant correlation with growth rates in number of plants and employment. These results suggest that the weak governance of the program caused the social norms of uncivicness inherited from the past to re-emerge. Compared to municipalities outside both the CasMez and the Kingdom borders, which experienced a cumulative growth rate of 22 percent for plants and 31 percent for employment between 1971 and 1991, those targeted by the program grew by an additional 1 percentage points in terms of both outcomes. Among municipalities formerly belonging to the Kingdom, however, the impact of the public funding was negative, with growth rates 4 and 5 percentage points lower, respectively. We still fail to find any impact for population growth. ${ }^{14}$

Table 3 provides a first robustness exercise. Panel A and B show results from Equation (1), ran using the sample of 514 municipalities selected through the PS routine, for the period 1951-1971 and 1971-1991, respectively. Overall, the sign and significance level of coefficients are confirmed. ${ }^{15}$ The point estimates differ to some extent though: the effect of CASMEZ in the first implementation phase is smaller, while that of the interaction between CASMEZ and KINGDOM in the second phase of the program is larger. Differences between conditional and unconditional estimates are much reduced in these regressions, as a result of the PS matching routine implemented to select the sample. Panel C of Table 3 addresses the concern that matching on the value of observable municipal traits in 1951 may not guarantee the homogeneity between treatment and control groups in the 1971-1991 regression. Municipalities similar in terms of observables in 1951 may have become significantly different by the time the second implementation phase began. Namely, the faster growth experienced by municipalities targeted by the CasMez between 1951 and 1971 might have weakened their comparability with respect to non-CasMez territories. To test whether the results obtained for the second implementation phase are due to lack of comparability between treatment and control groups, we run Equation (1) using a sample selected by matching municipalities on the basis of their observable characteristics in 1971. This sample includes 594 municipalities. The results of this exercise, presented in Panel $\mathrm{C}$ of Table 3, are very similar to those shown in Panel B: the point estimates on the variable CASMEZ $\times$ KINGDOM are now slightly larger.

Table 4 runs Equation (1) on a larger sample of municipalities, including all cities located within $100 \mathrm{~km}$ of the Kingdom's border. We expand the sample to additional type $(0,0)$ and type $(1,1)$ municipalities. More precise estimates could result from such doubling in the size of our sample. However, the presence of potential confounders and the heterogeneity of sample municipalities are likely to increase the further away they are located from the Kingdom's border. To address this concern, we only present results for a sample of municipalities within the $100 \mathrm{~km}$ bandwidth selected through the PS routine.

\footnotetext{
${ }^{14}$ We have checked for the presence of spatial autocorrelation by performing the standard Moran's I test on the residuals. Spatial autocorrelation is not an issue with our data.

${ }^{15}$ The fact that the results for the full sample are very similar to those referring to the PS sample, suggests that the amount of selection on observables is very minor and-according to Altnoji, Elder, and Taber (2005) classic argument-signals that selection on unobservables is likely to be also limited.
} 
TABLE 3: The Effects of CASMEZ and KINGDOM on the Outcomes (PS Sample, $50 \mathrm{~km}$ Bandwidth)

\begin{tabular}{|c|c|c|c|c|c|c|c|c|c|}
\hline \multirow[b]{2}{*}{ Dep. Variables } & \multicolumn{3}{|c|}{ Growth Rate of Plants } & \multicolumn{3}{|c|}{ Growth Rate of Employment } & \multicolumn{3}{|c|}{ Growth Rate of Population } \\
\hline & (1) & (2) & (3) & (4) & (5) & (6) & (7) & (8) & (9) \\
\hline \multicolumn{10}{|c|}{ Panel A. 1951-1971 } \\
\hline \multirow[t]{2}{*}{ CASMEZ } & $0.012^{* * * *}$ & $0.013^{* * * *}$ & $0.012^{* * *}$ & $0.026^{* *}$ & $0.022^{\text {**** }}$ & $0.021^{* *}$ & 0.007 & 0.008 & 0.008 \\
\hline & $(0.004)$ & $(0.005)$ & $(0.006)$ & $(0.011)$ & $(0.009)$ & $(0.010)$ & $(0.010)$ & $(0.011)$ & $(0.009)$ \\
\hline \multirow[t]{2}{*}{ KINGDOM } & 0.021 & 0.021 & 0.014 & 0.011 & 0.016 & 0.012 & 0.005 & 0.005 & 0.009 \\
\hline & $(0.016)$ & $(0.015)$ & $(0.016)$ & $(0.018)$ & $(0.013)$ & $(0.010)$ & $(0.021)$ & $(0.015)$ & $(0.016)$ \\
\hline \multirow{4}{*}{$\begin{array}{l}\text { CASMEZ } \times \\
\text { KINGDOM } \\
\text { Number of obs. } \\
R^{2}\end{array}$} & 0.007 & 0.007 & 0.013 & 0.006 & 0.012 & 0.008 & 0.005 & 0.009 & 0.012 \\
\hline & $(0.009)$ & $(0.011)$ & $(0.015)$ & $(0.020)$ & $(0.015)$ & $(0.012)$ & $(0.022)$ & $(0.024)$ & $(0.016)$ \\
\hline & 514 & 514 & 514 & 514 & 514 & 514 & 514 & 514 & 514 \\
\hline & 0.165 & 0.167 & 0.186 & 0.152 & 0.178 & 0.198 & 0.091 & 0.124 & 0.131 \\
\hline \multicolumn{10}{|c|}{ Panel B. 1971-1991 } \\
\hline \multirow[t]{2}{*}{ CASMEZ } & $0.014^{* *}$ & $0.012^{* *}$ & $0.015^{* * *}$ & $0.015^{\text {**** }}$ & $0.014^{* * * *}$ & 0.009 & 0.005 & 0.009 & 0.011 \\
\hline & $(0.006)$ & $(0.005)$ & $(0.005)$ & $(0.005)$ & $(0.005)$ & $(0.006)$ & $(0.021)$ & $(0.011)$ & $(0.010)$ \\
\hline \multirow[t]{2}{*}{ KINGDOM } & -0.004 & -0.007 & -0.008 & -0.016 & -0.010 & -0.015 & 0.006 & 0.007 & 0.009 \\
\hline & $(0.016)$ & $(0.010)$ & $(0.011)$ & $(0.013)$ & $(0.011)$ & $(0.014)$ & $(0.014)$ & $(0.014)$ & $(0.016)$ \\
\hline \multirow{4}{*}{$\begin{array}{l}\text { CASMEZ } \times \\
\text { KINGDOM } \\
\text { Number of obs. } \\
R^{2}\end{array}$} & $-0.041^{* * * * *}$ & $-0.045^{* * * *}$ & $-0.040^{* * *}$ & $-0.062^{* * * *}$ & $-0.072^{* * * *}$ & $-0.069^{* * * *}$ & 0.011 & 0.009 & 0.008 \\
\hline & $(0.017)$ & $(0.017)$ & $(0.019)$ & $(0.022)$ & $(0.019)$ & $(0.019)$ & $(0.021)$ & $(0.016)$ & $(0.016)$ \\
\hline & 514 & 514 & 514 & 514 & 514 & 514 & 514 & 514 & 514 \\
\hline & 0.109 & 0.165 & 0.171 & 0.127 & 0.154 & 0.199 & 0.095 & 0.171 & 0.173 \\
\hline
\end{tabular}

Panel C. 1971-1991 (matching with 1971 observables)

\begin{tabular}{lccccccccc}
\hline CASMEZ & $0.021^{* * *}$ & $0.022^{* * *}$ & $0.025^{* * *}$ & $0.012^{* * * *}$ & $0.011^{* * * *}$ & $0.009^{*}$ & 0.007 & 0.010 & 0.010 \\
& $(0.009)$ & $(0.010)$ & $(0.010)$ & $(0.005)$ & $(0.005)$ & $(0.005)$ & $(0.022)$ & $(0.019)$ & $(0.017)$ \\
KINGDOM & -0.007 & -0.009 & -0.009 & $-0.019^{* *}$ & -0.015 & -0.015 & 0.004 & 0.005 & 0.009 \\
& $(0.013)$ & $(0.013)$ & $(0.014)$ & $(0.009)$ & $(0.011)$ & $(0.012)$ & $(0.011)$ & $(0.011)$ & $(0.019)$ \\
CASMEZ $\times$ & $-0.055^{* * * *}$ & $-0.055^{* * *}$ & $-0.050^{* *}$ & $-0.079^{* * *}$ & $-0.073^{* * *}$ & $-0.065^{* * *}$ & 0.015 & 0.011 & 0.007 \\
$\quad$ KINGDOM & $(0.016)$ & $(0.017)$ & $(0.019)$ & $(0.019)$ & $(0.018)$ & $(0.021)$ & $(0.015)$ & $(0.014)$ & $(0.014)$ \\
Number of obs. & 594 & 594 & 594 & 594 & 594 & 594 & 594 & 594 & 594 \\
$R^{2}$ & 0.110 & 0.175 & 0.181 & 0.157 & 0.174 & 0.231 & 0.085 & 0.140 & 0.164 \\
Controls & No & Yes & Yes & No & Yes & Yes & No & Yes & Yes \\
Province-fixed & No & No & Yes & No & No & Yes & No & No & Yes \\
effects & & & & & & & & & \\
\hline
\end{tabular}

Note: OLS regressions, standard error in parentheses estimated based on Conley (1999), with a bandwidth of $50 \mathrm{~km}$. Observations include municipalities within $50 \mathrm{~km}$ from the KINGDOM boundary. Municipalities have been selected using a propensity score technique (kernel matching), which retains only observations that share common support, for the probability of being included in the CASMEZ area. Controls (as well as the vector of variables for the propensity score) include coastal town dummy, altitude, slope within the municipality, surface in $\mathrm{km}^{2}$, log of population and quadratic log of population in 1951, log of the number of plants and quadratic log of the number of plants in 1951, and log of employment and quadratic log of employment in 1951.

"Significant at 10 percent; ${ }^{* *}$ significant at 5 percent; ${ }^{* * *}$ significant at 1 percent.

The results of this exercise, reported in Table 4, confirm those of Table 3 . The expected gains in terms of precision and explanatory power fail to materialize, suggesting that the sample of $50 \mathrm{~km}$ is well suited for our investigation.

Table 5 provides an additional robustness exercise. To make sure that our results are not driven by specific trends at the region level, we exclude different sets of regions from the baseline sample of Table 2. Panel A documents the results we obtain by removing 
TABLE 4: The Effects of CASMEZ and KINGDOM on the Outcomes (PS Sample, $100 \mathrm{~km}$ Bandwidth)

\begin{tabular}{|c|c|c|c|c|c|c|c|c|c|}
\hline \multirow[b]{2}{*}{ Dep. Variables } & \multicolumn{3}{|c|}{ Growth Rate of Plants } & \multicolumn{3}{|c|}{ Growth Rate of Employment } & \multicolumn{3}{|c|}{ Growth Rate of Population } \\
\hline & (1) & (2) & (3) & (4) & (5) & (6) & (7) & (8) & (9) \\
\hline \multicolumn{10}{|c|}{ Panel A. 1951-1971 } \\
\hline CASMEZ & $\begin{array}{r}0.016^{*} \\
(0.009)\end{array}$ & $\begin{array}{l}0.019^{* * * *} \\
(0.007)\end{array}$ & $\begin{array}{l}0.022^{* * * *} \\
(0.007)\end{array}$ & $\begin{array}{c}0.024^{*} \\
(0.013)\end{array}$ & $\begin{array}{l}0.027^{\text {**** }} \\
(0.007)\end{array}$ & $\begin{array}{l}0.037^{\text {**** }} \\
(0.009)\end{array}$ & $\begin{array}{c}0.005 \\
(0.012)\end{array}$ & $\begin{array}{c}0.004 \\
(0.007)\end{array}$ & $\begin{array}{c}0.002 \\
(0.009)\end{array}$ \\
\hline KINGDOM & $\begin{array}{c}0.013 \\
(0.015)\end{array}$ & $\begin{array}{c}0.011 \\
(0.012)\end{array}$ & $\begin{array}{c}0.015 \\
(0.013)\end{array}$ & $\begin{array}{c}0.009 \\
(0.018)\end{array}$ & $\begin{array}{c}0.013 \\
(0.013)\end{array}$ & $\begin{array}{c}0.011 \\
(0.010)\end{array}$ & $\begin{array}{c}0.003 \\
(0.025)\end{array}$ & $\begin{array}{c}0.009 \\
(0.016)\end{array}$ & $\begin{array}{c}0.007 \\
(0.019)\end{array}$ \\
\hline $\begin{array}{l}\text { CASMEZ } \times \\
\text { KINGDOM }\end{array}$ & $\begin{array}{c}0.005 \\
(0.022)\end{array}$ & $\begin{array}{c}0.009 \\
(0.015)\end{array}$ & $\begin{array}{c}0.008 \\
(0.016)\end{array}$ & $\begin{array}{c}0.006 \\
(0.020)\end{array}$ & $\begin{array}{c}0.012 \\
(0.015)\end{array}$ & $\begin{array}{c}0.008 \\
(0.012)\end{array}$ & $\begin{array}{c}0.007 \\
(0.031)\end{array}$ & $\begin{array}{c}0.003 \\
(0.017)\end{array}$ & $\begin{array}{c}0.002 \\
(0.020)\end{array}$ \\
\hline $\begin{array}{l}\text { Number of obs. } \\
R^{2}\end{array}$ & $\begin{array}{l}1,189 \\
0.145 \\
\end{array}$ & $\begin{array}{l}1,189 \\
0.147 \\
\end{array}$ & $\begin{array}{l}1,189 \\
0.166 \\
\end{array}$ & $\begin{array}{l}1,189 \\
0.140 \\
\end{array}$ & $\begin{array}{l}1,189 \\
0.161 \\
\end{array}$ & $\begin{array}{l}1,189 \\
0.190 \\
\end{array}$ & $\begin{array}{l}1,189 \\
0.099 \\
\end{array}$ & $\begin{array}{l}1,189 \\
0.142 \\
\end{array}$ & $\begin{array}{l}1,189 \\
0.144 \\
\end{array}$ \\
\hline \multicolumn{10}{|c|}{ Panel B. 1971-1991 } \\
\hline CASMEZ & $\begin{array}{c}0.009 \\
(0.007)\end{array}$ & $\begin{array}{l}0.011^{*} \\
(0.005)\end{array}$ & $\begin{array}{l}0.013^{* *} \\
(0.005)\end{array}$ & $\begin{array}{c}0.015 \\
(0.012)\end{array}$ & $\begin{array}{c}0.009 \\
(0.006)\end{array}$ & $\begin{array}{r}0.010^{*} \\
(0.005)\end{array}$ & $\begin{array}{c}0.005 \\
(0.023)\end{array}$ & $\begin{array}{c}0.007 \\
(0.009)\end{array}$ & $\begin{array}{c}0.009 \\
(0.009)\end{array}$ \\
\hline KINGDOM & $\begin{array}{c}0.001 \\
(0.013)\end{array}$ & $\begin{array}{c}-0.007 \\
(0.010)\end{array}$ & $\begin{array}{r}-0.008 \\
(0.011)\end{array}$ & $\begin{array}{c}-0.015 \\
(0.012)\end{array}$ & $\begin{array}{c}-0.011 \\
(0.012)\end{array}$ & $\begin{array}{r}-0.015 \\
(0.012)\end{array}$ & $\begin{array}{c}0.003 \\
(0.015)\end{array}$ & $\begin{array}{c}0.004 \\
(0.011)\end{array}$ & $\begin{array}{c}0.005 \\
(0.015)\end{array}$ \\
\hline $\begin{array}{l}\text { CASMEZ } \times \\
\text { KINGDOM }\end{array}$ & $\begin{array}{c}0.029 \\
(0.025)\end{array}$ & $\begin{array}{c}-0.039^{* *} \\
(0.015)\end{array}$ & $\begin{array}{c}-0.045^{\text {**** }} \\
(0.015)\end{array}$ & $\begin{array}{r}-0.049^{*} \\
(0.022)\end{array}$ & $\begin{array}{c}-0.052^{\text {**** }} \\
(0.014)\end{array}$ & $\begin{array}{c}-0.051^{* * * *} \\
(0.016)\end{array}$ & $\begin{array}{c}0.009 \\
(0.025)\end{array}$ & $\begin{array}{c}0.004 \\
(0.013)\end{array}$ & $\begin{array}{c}0.004 \\
(0.015)\end{array}$ \\
\hline Number of obs. & 1,189 & 1,189 & 1,189 & 1,189 & 1,189 & 1,189 & 1,189 & 1,189 & 1,189 \\
\hline$R^{2}$ & 0.110 & 0.155 & 0.161 & 0.125 & 0.144 & 0.180 & 0.045 & 0.134 & 0.139 \\
\hline Controls & No & Yes & Yes & No & Yes & Yes & No & Yes & Yes \\
\hline $\begin{array}{l}\text { Province-fixed } \\
\text { effects }\end{array}$ & No & No & Yes & No & No & Yes & No & No & Yes \\
\hline
\end{tabular}

Note: OLS regressions, standard error in parentheses estimated based on Conley (1999), with a bandwidth of $100 \mathrm{~km}$. Observations include municipalities within $100 \mathrm{~km}$ from the KINGDOM boundary. Municipalities have been selected by using a propensity score technique (kernel matching), which retains only observations that share common support, for the probability of being included in the CASMEZ area. Controls (as well as the vector of variables for the propensity score) include coastal town dummy, altitude, slope within the municipality, surface in $\mathrm{km}^{2}$, log of population and quadratic $\log$ of population in 1951, log of the number of plants and quadratic log of the number of plants in 1951, and log of employment and quadratic log of employment in 1951.

"Significant at 10 percent; ${ }^{* *}$ significant at 5 percent; ${ }^{* * *}$ significant at 1 percent.

Campania and Lazio, while Panel B presents the estimates from a sample that excludes Marche, Umbria, Abruzzo and Molise. For economy of space, we only show estimates from regressions including both controls and province-fixed effects. Our results are robust to the different sample specifications, even though the estimates are less precise, given the reduced sample size.

This robustness test also provides interesting insights on potential sources of heterogeneity in our results, and their generalizability beyond the narrow territory considered in our empirical analysis. The territory of the Papal States in the seventeenth century, which forms the basis of our empirical analysis, included former Seigneuries and States, such as the Seigneury of Perugia and the Duchy of Urbino (in the regions of Marche and Umbria, respectively) that, although part of the Papal States since the middle of the fourteenth century, had remained semi-independent until the 16th century. ${ }^{16}$ There is,

${ }^{16}$ The Constitutiones Egidiane of 1357 describe the articulation of the Papal States' provinces, after the military campaigns conducted by Cardinal Egidio Albornoz brought these territories under formal control of the Pope (Ermini, 1893). 
TABLE 5: The Effects of CASMEZ and KINGDOM on the Outcomes (Full Sample, $50 \mathrm{~km}$ Bandwidth, Excluding Regions)

Growth Rate Growth Rate Growth Rate Growth Rate Growth Rate Growth Rate of Plants of Employment of Population of Plants of Employment of Population

Dep. Variables

(1)

(2)

(3)

(4)

(5)

(6)

Panel A. Excluding Campania and Lazio

\begin{tabular}{lcccccc}
\hline & \multicolumn{3}{c}{$1951-1971$} & & \multicolumn{3}{c}{$1971-1991$} \\
\hline CASMEZ & 0.018 & $0.045^{* * *}$ & 0.003 & $0.015^{*}$ & 0.011 & 0.005 \\
& $(0.010)$ & $(0.015)$ & $(0.011)$ & $(0.008)$ & $(0.008)$ & $(0.010)$ \\
KINGDOM & 0.011 & 0.013 & 0.006 & -0.010 & -0.011 & 0.004 \\
& $(0.015)$ & $(0.016)$ & $(0.022)$ & $(0.015)$ & $(0.015)$ & $(0.019)$ \\
CASMEZ $\times$ KINGDOM & 0.006 & 0.006 & 0.005 & $-0.055^{*}$ & $-0.059^{* *}$ & -0.009 \\
& $(0.020)$ & $(0.016)$ & $(0.024)$ & $(0.027)$ & $(0.028)$ & $(0.021)$ \\
Number of obs. & 310 & 310 & 310 & 310 & 310 & 310 \\
$R^{2}$ & 0.123 & 0.132 & 0.095 & 0.142 & 0.133 & 0.112 \\
\hline
\end{tabular}

Panel B. Excluding Marche, Umbria, Abruzzo, and Molise

\begin{tabular}{lcccccc}
\hline & \multicolumn{3}{c}{$1951-1971$} & \multicolumn{3}{c}{$1971-1991$} \\
\hline CASMEZ & $0.024^{* *}$ & $0.055^{* * *}$ & 0.001 & 0.012 & 0.009 & 0.012 \\
KINGDOM & $(0.011)$ & $(0.017)$ & $(0.013)$ & $(0.009)$ & $(0.005)$ & $(0.012)$ \\
& 0.009 & 0.007 & 0.004 & -0.002 & -0.025 & 0.004 \\
CASMEZ $\times$ KINGDOM & $(0.018)$ & $(0.012)$ & $(0.025)$ & $(0.015)$ & $(0.015)$ & $(0.018)$ \\
& 0.003 & 0.011 & 0.001 & $-0.049^{* *}$ & $-0.045^{*}$ & 0.011 \\
Number of obs. & $(0.019)$ & $(0.018)$ & $(0.025)$ & $(0.024)$ & $(0.023)$ & $(0.015)$ \\
$R^{2}$ & 297 & 297 & 297 & 297 & 297 & 297 \\
Controls & 0.144 & 0.159 & 0.081 & 0.150 & 0.157 & 0.101 \\
Province-fixed effects & Yes & Yes & Yes & Yes & Yes & Yes \\
& Yes & Yes & Yes & Yes & Yes & Yes \\
\hline
\end{tabular}

Note: OLS regressions, standard error in parentheses estimated based on Conley (1999), with a bandwidth of $50 \mathrm{~km}$. Observations include municipalities within $50 \mathrm{~km}$ from the KINGDOM boundary. Controls include coastal town dummy, altitude, slope within the municipality, surface in $\mathrm{km}^{2}$, log of population and quadratic log of population in 1951, log of the number of plants and quadratic log of the number of plants in 1951, and log of employment and quadratic log of employment in 1951.

*Significant at 10 percent; ${ }^{* *}$ significant at 5 percent; ${ }^{* * *}$ significant at 1 percent.

therefore, heterogeneity in historical administrative and political rules between different parts of the Papal States. By removing the regions of Marche, Umbria, Abruzzo and Molise from the analysis, we test the robustness of our results over the territories that remained always under strict papal rule. Moreover, the estimates removing Lazio and Campania provide evidence of the effect of historical legacy and development policy on territories that were more similar to the Seigneuries and States found in northern and central Italy, and that thus were more likely to have experienced a greater development of civicness in the Middle Ages, than those in the western part of the Papal States. Indeed, Table 5 shows that the magnitude of the negative CASMEZ $\times$ KINGDOM coefficients is slightly larger in Panel B than in Panel A, suggesting a stronger difference in policy effectiveness in 1971-1991 between territories formerly under the Kingdom and the more recent acquisitions of the Papal States, than between the Kingdom and the core area of Papal dominance.

The robustness checks implemented so far do not guarantee that our results are free from omitted variables bias. Given the scarcity of municipal-level data referring to the 
TABLE 6: Placebo Experiment (PS Sample, $50 \mathrm{~km}$ Bandwidth)

\begin{tabular}{|c|c|c|c|c|c|c|c|c|c|}
\hline \multirow[b]{2}{*}{ Dep. Variables } & \multicolumn{3}{|c|}{ Growth Rate of Plants } & \multicolumn{3}{|c|}{ Growth Rate of Employment } & \multicolumn{3}{|c|}{ Growth Rate of Population } \\
\hline & (1) & (2) & (3) & (4) & (5) & (6) & (7) & (8) & (9) \\
\hline \multicolumn{10}{|l|}{ Panel A. 1951-1971 } \\
\hline CASMEZ & $\begin{array}{c}0.007 \\
(0.009)\end{array}$ & $\begin{array}{c}0.009 \\
(0.007)\end{array}$ & $\begin{array}{l}0.006 \\
(0.007)\end{array}$ & $\begin{array}{c}0.006 \\
(0.019)\end{array}$ & $\begin{array}{c}0.003 \\
(0.019)\end{array}$ & $\begin{array}{c}0.006 \\
(0.022)\end{array}$ & $\begin{array}{c}0.002 \\
(0.014)\end{array}$ & $\begin{array}{c}0.001 \\
(0.017)\end{array}$ & $\begin{array}{c}0.002 \\
(0.019)\end{array}$ \\
\hline KINGDOM & $\begin{array}{c}0.003 \\
(0.019)\end{array}$ & $\begin{array}{c}0.006 \\
(0.018)\end{array}$ & $\begin{array}{c}0.007 \\
(0.019)\end{array}$ & $\begin{array}{c}0.006 \\
(0.021)\end{array}$ & $\begin{array}{c}0.009 \\
(0.025)\end{array}$ & $\begin{array}{c}0.002 \\
(0.027)\end{array}$ & $\begin{array}{c}0.004 \\
(0.029)\end{array}$ & $\begin{array}{c}0.003 \\
(0.031)\end{array}$ & $\begin{array}{c}0.003 \\
(0.036)\end{array}$ \\
\hline CASMEZ $\times$ KINGDOM & $\begin{array}{c}0.005 \\
(0.011)\end{array}$ & $\begin{array}{c}0.004 \\
(0.015)\end{array}$ & $\begin{array}{c}0.001 \\
(0.013)\end{array}$ & $\begin{array}{c}0.004 \\
(0.025)\end{array}$ & $\begin{array}{c}0.005 \\
(0.055)\end{array}$ & $\begin{array}{c}0.007 \\
(0.022)\end{array}$ & $\begin{array}{c}0.001 \\
(0.032)\end{array}$ & $\begin{array}{c}0.002 \\
(0.034)\end{array}$ & $\begin{array}{c}0.002 \\
(0.036)\end{array}$ \\
\hline $\begin{array}{l}\text { Number of obs. } \\
R^{2}\end{array}$ & $\begin{array}{l}514 \\
0.007\end{array}$ & $\begin{array}{l}514 \\
0.013 \\
\end{array}$ & $\begin{array}{l}514 \\
0.023\end{array}$ & $\begin{array}{l}514 \\
0.003\end{array}$ & $\begin{array}{l}514 \\
0.022 \\
\end{array}$ & $\begin{array}{l}514 \\
0.024\end{array}$ & $\begin{array}{c}514 \\
0.010\end{array}$ & $\begin{array}{c}514 \\
0.014\end{array}$ & $\begin{array}{c}514 \\
0.018 \\
\end{array}$ \\
\hline \multicolumn{10}{|l|}{ Panel B. 1971-1991 } \\
\hline CASI & $\begin{array}{c}0.004 \\
(0.012)\end{array}$ & $\begin{array}{c}0.003 \\
(0.015)\end{array}$ & $\begin{array}{c}0.002 \\
(0.015)\end{array}$ & $\begin{array}{c}0.006 \\
(0.019)\end{array}$ & $\begin{array}{c}0.008 \\
(0.026)\end{array}$ & $\begin{array}{c}0.006 \\
(0.025)\end{array}$ & $\begin{array}{c}0.005 \\
(0.023)\end{array}$ & $\begin{array}{c}0.004 \\
(0.021)\end{array}$ & $\begin{array}{c}0.004 \\
(0.019)\end{array}$ \\
\hline KINGDOM & $\begin{array}{c}-0.001 \\
(0.019)\end{array}$ & $\begin{array}{c}-0.004 \\
(0.020)\end{array}$ & $\begin{array}{c}-0.004 \\
(0.024)\end{array}$ & $\begin{array}{c}-0.005 \\
(0.031)\end{array}$ & $\begin{array}{c}-0.001 \\
(0.032)\end{array}$ & $\begin{array}{c}-0.002 \\
(0.032)\end{array}$ & $\begin{array}{c}0.003 \\
(0.035)\end{array}$ & $\begin{array}{c}0.002 \\
(0.031)\end{array}$ & $\begin{array}{c}0.002 \\
(0.035)\end{array}$ \\
\hline CASMEZ $\times$ KINGDOM & $\begin{array}{c}-0.004 \\
(0.029)\end{array}$ & $\begin{array}{c}-0.002 \\
(0.025)\end{array}$ & $\begin{array}{c}-0.004 \\
(0.021)\end{array}$ & $\begin{array}{c}-0.004 \\
(0.028)\end{array}$ & $\begin{array}{c}-0.001 \\
(0.031)\end{array}$ & $\begin{array}{r}-0.007 \\
(0.016)\end{array}$ & $\begin{array}{c}0.002 \\
(0.025)\end{array}$ & $\begin{array}{c}0.003 \\
(0.033)\end{array}$ & $\begin{array}{c}0.003 \\
(0.035)\end{array}$ \\
\hline $\begin{array}{l}\text { Number of obs. } \\
R^{2}\end{array}$ & 514 & 514 & 514 & 514 & 514 & 514 & 514 & 514 & $\begin{array}{c}514 \\
0.044\end{array}$ \\
\hline $\begin{array}{l}R^{2} \\
\text { Con }\end{array}$ & $\begin{array}{l}0.009 \\
\text { No }\end{array}$ & $\begin{array}{l}0.015 \\
\text { Yes }\end{array}$ & $\begin{array}{l}0.031 \\
\text { Yes }\end{array}$ & $\begin{array}{l}0.012 \\
\text { No }\end{array}$ & $\begin{array}{l}0.014 \\
\text { Yes }\end{array}$ & $\begin{array}{l}0.017 \\
\text { Yes }\end{array}$ & $\begin{array}{l}0.022 \\
\text { No }\end{array}$ & $\begin{array}{c}0.031 \\
\text { Yes }\end{array}$ & $\begin{array}{l}0.044 \\
\text { Yes }\end{array}$ \\
\hline Province-fixed effects & No & No & Yes & No & No & Yes & No & No & Yes \\
\hline
\end{tabular}

Note: OLS regressions, standard error in parentheses estimated based on Conley (1999), with a bandwidth of $100 \mathrm{~km}$. Observations include municipalities within $100 \mathrm{~km}$ from the KINGDOM boundary. Municipalities have been selected using a propensity score technique (kernel matching), which retains only observations that share common support, for the probability of being included in the CASMEZ area. Controls (as well as the vector of variables for the propensity score) include coastal town dummy, altitude, slope within the municipality, surface in $\mathrm{km}^{2}$, log of population and quadratic $\log$ of population in 1951, log of the number of plants and quadratic log of the number of plants in 1951, and log of employment and quadratic log of employment in 1951.

"Significant at 10 percent; ${ }^{* *}$ significant at 5 percent; ${ }^{* * *}$ significant at 1 percent.

period post-World War II, this is a serious concern. As a more direct test of the influence of unobserved heterogeneity on our results, Table 6 presents results from a placebo experiment. The logic behind this exercise is the following. So far, we have identified the effect of cultural legacy on policy effectiveness by comparing neighboring (and similar) municipalities with different exposure to the program and history. To the extent that we are mistakenly attributing to our variables of interest something specific to the area, but unrelated to the CasMez and cultural legacy, an arbitrary variation in the policy and historical boundaries will only marginally affect our results. If the historical and policy boundaries are not driving our estimates, moving away from them should not influence our findings. In Table 6 we report results obtained by moving the CasMez border $10 \mathrm{~km}$ to the south. In terms of treatment groups, this shift amounts to arbitrarily attributing some municipalities of type $(1,0)$ to the false type $(0,0)$ and some municipalities of type $(1,1)$ to the false type $(0,1)$. The results of the placebo test are reassuring, in that none of the regularities previously shown hold any longer. ${ }^{17}$

\footnotetext{
${ }^{17}$ We also conduct a different placebo test, by moving the Kingdom border $10 \mathrm{~km}$ to the north, and obtain similar null results.
} 
TABLE 7: Growth Differences between Types $(1,1)$ and $(0,0)$ Municipalities, Differently Located (PS Sample)

\begin{tabular}{|c|c|c|c|c|c|c|c|c|c|}
\hline \multirow[b]{2}{*}{ Dep. Variables } & \multicolumn{3}{|c|}{ Growth Rate of Plants } & \multicolumn{3}{|c|}{ Growth Rate of Employment } & \multicolumn{3}{|c|}{ Growth Rate of Population } \\
\hline & (1) & (2) & (3) & (4) & (5) & (6) & (7) & (8) & (9) \\
\hline \multicolumn{10}{|l|}{ Panel A. 1951-1971 } \\
\hline \multirow{2}{*}{ Types $(1,1)^{\mathrm{a}}$} & $0.033^{* * * *}$ & $* 0.045^{* * *}$ & $0.042^{* * * *}$ & $* 0.024$ & $0.035^{* * *}$ & $0.039^{* * * *}$ & 0.042 & $0.045^{* *}$ & $0.047^{* * * *}$ \\
\hline & $(0.010)$ & $(0.009)$ & $(0.009)$ & $(0.015)$ & $(0.014)$ & $(0.013)$ & $(0.013)$ & $(0.012)$ & $(0.012)$ \\
\hline Number of obs. & 312 & 312 & 312 & 312 & 312 & 312 & 312 & 312 & 312 \\
\hline$R^{2}$ & 0.172 & 0.192 & 0.234 & 0.198 & 0.211 & 0.255 & 0.172 & 0.287 & 0.302 \\
\hline \multirow[t]{2}{*}{ Types $(0,0)^{b}$} & $-0.042^{* * * *}$ & $-0.055^{* * *}$ & $-0.063^{* * * * *}$ & $-0.022^{* *}$ & $-0.031^{* * *}$ & $-0.033^{* * * *}$ & $-0.031^{* * *}$ & $-0.028 *$ & -0.025 \\
\hline & $(0.009)$ & $(0.012)$ & $(0.012)$ & $(0.012)$ & $(0.013)$ & $(0.011)$ & $(0.013)$ & $(0.014)$ & $(0.016)$ \\
\hline Number of obs. & 297 & 297 & 297 & 297 & 297 & 297 & 297 & 297 & 297 \\
\hline$R^{2}$ & 0.197 & 0.221 & 0.253 & 0.165 & 0.198 & 0.196 & 0.143 & 0.155 & 0.252 \\
\hline \multicolumn{10}{|l|}{ Panel B. 1971-1991 } \\
\hline \multirow[t]{2}{*}{ Types $(1,1)^{\mathrm{a}}$} & 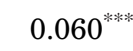 & $0.066^{* * * *}$ & $* 0.069^{* * * *}$ & * $0.048^{* * * *}$ & 0.066 *** & $0.069^{* * * *}$ & 0.009 & 0.008 & 0.004 \\
\hline & $(0.015)$ & $(0.015)$ & $(0.016)$ & $(0.016)$ & $(0,018)$ & $(0.018)$ & $(0.022)$ & $(0.025)$ & $(0.019)$ \\
\hline Number of obs. & 312 & 312 & 312 & 312 & 312 & 312 & 312 & 312 & 312 \\
\hline$R^{2}$ & 0.168 & 0.183 & 0.276 & 0.102 & 0.155 & 0.269 & 0.009 & 0.121 & 0.127 \\
\hline \multirow[t]{2}{*}{ Types $(0,0)^{\mathrm{b}}$} & $-0.048^{* * * *}$ & $-0.057^{* * *}$ & $-0.061^{* * *}$ & *0.023 & $-0.036^{* * *}$ & $-0.034^{* *}$ & 0.005 & 0.007 & 0.003 \\
\hline & $(0.013)$ & $(0.012)$ & $(0.009)$ & $(0.013)$ & $(0.015)$ & $(0.016)$ & $(0.034)$ & $(0.029)$ & $(0.033)$ \\
\hline Number of obs. & 297 & 297 & 297 & 297 & 297 & 297 & 297 & 297 & 297 \\
\hline$R^{2}$ & 0.179 & 0.205 & 0.231 & 0.172 & 0.204 & 0.267 & 0.022 & 0.031 & 0.044 \\
\hline Control & No & Yes & Yes & No & Yes & Yes & No & Yes & Yes \\
\hline Province-fixed effects & is No & No & Yes & No & No & Yes & No & No & Yes \\
\hline
\end{tabular}

Note: LS regressions, in parentheses standard error estimates based on Conley (1999), with a bandwidth of $100 \mathrm{~km}$. Observations include municipalities within $100 \mathrm{~km}$ from the CASMEZ boundary. Municipalities have been selected by using a propensity score technique (kernel matching), which retains only observations that share the common support, for the probability of being included in the CASMEZ area. Controls (as well as the vector of variables for the propensity score) include coastal town dummy, altitude, slope within the municipality, surface in $\mathrm{km}^{2}$, log of population and quadratic $\log$ of population in 1951, log of the number of plants and quadratic log of the number of plants in 1951, and log of employment and quadratic log of employment in 1951.

aIdentifies the differences in the outcomes between Type $(1,1)$ municipalities within $50 \mathrm{~km}$ from Kingdom's border and a control group of PS-selected Type $(1,1)$ municipalities located further south, beyond the $50 \mathrm{~km}$ threshold.

bIdentifies the differences in the outcomes between Type $(0,0)$ municipalities within $50 \mathrm{~km}$ from Kingdom's border and a control group of PS-selected Type $(0,0)$ municipalities located further north, beyond the $50 \mathrm{~km}$ threshold and not formerly belonging to the Papal States.

*Significant at 10 percent; ${ }^{* *}$ significant at 5 percent; ${ }^{* * *}$ significant at 1 percent.

A final issue addressed by our empirical analysis concerns the external validity of our results, derived from a sample of municipalities within close distance from the Kingdom's historical border. Can we draw from our findings conclusions relevant to areas further from this border within Italy? As explained in Section 4, we suspect that our results may underestimate the impact of the Kingdom's cultural legacy on the CasMez's effectiveness for two main reasons. First, the presence of spillover effects in terms of cultural traits and development between neighboring municipalities might attenuate treatment effects. Second, our identification strategy relies on the comparison between municipalities located within the Kingdom and the Papal States: according to Putnam et al. (1993), differences in civicness between these two areas are the least pronounced over the Italian territory. We already provided suggestive evidence on the likelihood of such under-estimation in our comment to Table 5 above. Here, we complement that evidence with a comparison of the 
development performances of municipalities lying within and outside the territory from which we draw our main sample. An implication of the lower threshold argument is that our sample of municipalities of type $(1,1)$ close to the Kingdom's border should perform relatively better than municipalities of the same type located further south. Similarly, municipalities of type $(0,0)$ near the border should perform relatively worse than similar municipalities located further north, especially those within areas formerly belonging to communal republics and seigneuries. To test these implications we implement two additional checks. We use the same empirical specification adopted so far (Equation (1)) and we change the definitions of the treatment/control grouping. We take all municipalities of type $(1,1)$ lying within $50 \mathrm{~km}$ from the Kingdom's border and compare them with a sample of similar municipalities located further than $50 \mathrm{~km}$ away to the south and selected by PS matching on the basis of their 1951 characteristics. Similarly, we take all municipalities of type $(0,0)$ in our sample and compare them with a sample of similar municipalities located further than $50 \mathrm{~km}$ away to the north from the border and selected by PS matching on the basis of their 1951 characteristics. In this latter case, control municipalities are drawn from territories not formerly belonging to the Papal States. Table 7 reports the main results from this exercise: the further north a municipality is located, the better its development trajectory is. The relationship between longitude and economic performance is significant both for type $(1,1)$ and type $(0,0)$ municipalities. Panel B of Table 7 also shows that during the second implementation phase, when the combined effect of the CasMez and the Kingdom's legacy led to negative growth rates in type $(1,1)$ municipalities within our sample, the difference in economic performance between these municipalities and their counterparts outside our sample increased. Overall, these comparisons seem to confirm that the effects we estimate for the area close to the Kingdom's border may represent a lower bound of the actual influence of historical legacy on the CasMez's performance.

\section{CONCLUSIONS}

Historical institutions are found to affect contemporary levels of development and institutional performance (Putnam et al., 1993; Acemoglu, Johnson, and Robinson, 2001; Guiso et al., 2008; Felice, 2013; Felice and Vasta, 2015). The long-term persistence of historical legacies appears to work through their influence on social and cultural norms (Guiso et al., 2008; Nunn, 2009). Italy is a good setting to test the influence of history on current economic and policy performance, since it is a country where regions formerly belonging to a wide range of different regimes now coexist under a unique institutional and legal framework. Studies exploiting these features of the Italian setting show how historical institutions can explain the heterogeneous economic and institutional performance, cultural values and endowments of social norms observed in different areas of the country (Putnam et al., 1993; de Blasio and Nuzzo, 2010; Giordano and Tommasino, 2011).

This paper makes two main contributions to the literature on history and development. First, it shows that the performance of local development policies can be affected by the cultural traits prevailing in targeted areas. Second, the results presented here demonstrate that not all policies are equally vulnerable to the influence of historical legacies. Namely, the quality and level of governance appear critical in insulating policy effects from local cultural factors. In the case of the CasMez, no differences in the level of local development it induced are observed, depending on historical legacy, when the program was free from political influences. However, such differences emerged as soon as the program was captured by local political interests, with territories formerly belonging to the Kingdom performing worse than those located outside the Kingdom's borders. 
One channel through which differing levels of historically determined social capital may have affected CasMez's impact in this phase is by influencing the allocation of the funds. The shift from the first to the second phase of the CasMez primarily determined a change in the way funds were allocated: while in the first-stage allocation decisions were based on objective cost-effectiveness criteria, in the second stage such decisions were left to the discretion of local political elites. The outcome of this decision would probably depend on whether elites were embedded within social networks based on family or kinship ties, or on more far-reaching ties, such as those established through engagement in civic activities. The characterization of the relationship between social network structures and social capital contexts made in the literature leads us to hypothesize a more efficient allocation of the funds in the latter than in the former context, consistent with our findings on the impact of such disbursement decisions. Moreover, it is possible that local elites, being more attentive to their local electorate, would prefer consumption transfers to structural investments as way to allocate funds, as the former are more targetable than the latter.

Our results have potentially interesting implications. First, they confirm the persistence of historical legacies, whose effects may re-emerge after decades of dormancy. We believe this is a piece of evidence that might help explain some unresolved puzzles in the literature on the effects of culture. For instance, it remains debated why social capital impacts on development in some periods but not in others. ${ }^{18}$ As for the case of Italy, the trend in the north-south economic gap changed sign several times over the decades. In this perspective, our results suggest that the negative effects of inheriting social norms of low civicness and cooperation only emerge in the presence of certain enabling conditions. In our specific case, the re-emergence is due to the particular governance quality that the CasMez experienced after 1971.

Second, our results are consistent with a theory on the causes of Italy's dualism that can be seen as integrating explanations based on cultural traits. For instance, Felice's (2013) view is that the intellectual élites of the Kingdom of Naples waned after the failed attempt at modernization of the late-18th century and the repression that followed the Bourbons Restoration. This interpretation thus sees the south as suffering more from the low quality of its elites than from the long-lasting influence of cultural traits. Our findings are consistent with a critical role played by local elites, as it is the shift in the administrative power from the national to the local level that creates the conditions for the emergence of the negative effect of uncooperative historical norms formed in the early modern period.

Third, our findings may be relevant to the current debate on centralism versus regionalism in Italy. While the evidence presented here refers to the past and is not directly applicable to the current discussion, it nonetheless supports the view that decentralization may be harmful for those areas endowed with uncooperative social values.

Of course, our methodology relies on econometric techniques to identify the net effects of a multitude of historical and political factors, and is thus not fit for answering "big think" economic history questions. For instance, the broad classifications, in terms of both temporal and spatial cutoffs, on which our empirical analysis is based, cut short on complex historical aspects, like the central and regional governance of the Papal State versus the Kingdom of Naples, and the historical nature and functions of their local elites. These aspects might be worth exploring to move beyond the explanation based on generically defined cultural traits that we provide here. Therefore, while our results are

${ }^{18}$ This is also related to the issue of the appropriate "critical juncture," to borrow Acemoglu et al.'s (2008) words, for the start of the regional diverging growth path. 
consistent with general insights of specific historical theories, they cannot be thought of directly proving or confuting any of them, nor of shedding light on their more nuanced arguments.

Similarly, our analysis cannot uniquely identify whether a single factor, among the changes introduced between the first and second stage of the CasMez, is responsible for the effects we find. As discussed in section 3 above, the second stage of the CasMez differed from the first not only in terms of the quality of the people in charge of the funds' allocation and of the insulation of the decision process from local and political pressure groups, but also in terms of the type of projects financed and of the level at which the power to decide the funds' allocation was concentrated. While we claim that the critical aspect that determined the reduced effectiveness of the CasMez in the Kingdom's regions is its permeability to local interests during the second stage, we cannot rule out other channels of influence. Still, we do not believe that our results imply a negative view of decentralization processes in general, but suggest that such processes should be accompanied by the establishment of transparent and effective accountability, monitoring and sanctioning mechanisms at the local level, to prevent potentially negative historical legacies to re-emerge.

Overall, with reference to the wider debate on the influence of history on development, our findings suggest that historical legacies may re-emerge even after decades of dormancy, but that their influence can be escaped through good policy designs and governance systems.

\section{REFERENCES}

Accetturo, Antonio, Guido de Blasio, and Lorenzo Ricci. 2014. "A Tale of an Unwanted Outcome: Transfers and Local Endowments of Trust and Cooperation," Journal of Economic Behavior and Organization, 102, 74-89.

Acemoglu, Daron, Simon Johnson, James A Robinson, and Pierre Yared. 2008. "Income and Democracy," American Economic Review, 98, 808-842.

Acemoglu, Daron, Simon Johnson, and James A Robinson. 2001. "The Colonial Origins of Comparative Development: An Empirical Investigation," American Economic Review, 91(5),1369-1401.

Albanese, Giuseppe, Guido de Blasio, and Paolo Sestito. 2016. "My Parents Taught Me. Evidence on the Family Transmission of Values," Journal of Population Economics, 29(2), 571-592.

Altnoji, Joseph G., Todd E. Elder, and Christopher R. Taber. 2005. "Selection on Observed and Unobserved Variables: Assessing the Effectiveness of Catholic Schools," Journal of Political Economy, 113(1), 151-184.

Banerjee,Abhijit, Raghabendra Chattopadhyay, Esther Duflo, Daniel Keniston, and Nina Singh. 2012. "Can Institutions be Reformed from Within? Evidence from a Randomized Experiment with the Rajasthan Police," National Bureau of Economic Research Working Paper Series No. 17912. Cambridge, MA: National Bureau of Economic Research.

Barone, Guglielmo and Sauro Mocetti. 2011. "Tax Morale and Public Spending Inefficiency," International Tax and Public Finance, 18(6), 724-749.

Barone, Guglielmo and Guido de Blasio. 2013. "Electoral Rules and Voter Turnout," International Review of Law and Economics, 36, 25-35.

Battilani, Patrizia and Francesca Fauri. 2008. Mezzo secolo di economia italiana, 1945-2008. Bologna: Il Mulino.

Beaman, Lori, Raghabendra Chattopadhyay, Esther Duflo, Rohini Pande, and Petja Topalova. 2009. "Powerful Women: Does Exposure Reduce Bias?" The Quarterly Journal of Economics, 124(4), 1497-1540.

Beaman, Lori, Esther Duflo, Rohini Pande, and Petja Topalova. 2012. "Female Leadership Raises Aspirations and Educational Attainment for Girls: A Policy Experiment in India," Science, 335(6068), 582-586.

Becker, Sasha O., Katrin Boeckh, Christa Hainz, and Ludger Woessmann. 2015. "The Empire Is Dead, Long Live the Empire! Long-Run Persistence of Trust and Corruption in the Bureaucracy," The Economic Journal, 126(590), 40-74.

Bevilacqua, Piero. 1993. Breve storia dell'Italia meridionale dall'Ottocento a oggi. Rome: Donzelli.

Bosker, Maarten, Steven Brakman, Harry Garretsen, Herman De Jong, and Marc Schramm. 2008. "Ports, Plagues and Politics, Explaining Italian City Growth 1300-1861," European Review of Economic History, 12, 97-131

Cafiero, Salvatore. 2000. Storia dell'intervento straordinario nel Mezzogiorno (1950-2003). Manduria-Bari-Roma: Lacaita Editore.

Carlyle, Margaret. 1962. The Awakening of Southern Italy. London: Oxford University Press. 
Cassar, Alessandra, Giovanna d'Adda, and Pauline Grosjean. 2013. "Institutional Quality, Culture, and Norms of Cooperation: Evidence from a Behavioral Field Experiment," Journal of Law and Economics, 57, 821-863.

Daniele, Vittorio and Paolo Malanima. 2007. "Il prodotto delle regioni e il divario Nord-Sud in Italia (1861-2004)," Rivista di Politica Economica, 97(2), 267-316.

de Blasio, Guido and Giorgio Nuzzo. 2010. "Historical Traditions of Civicness and Local Economic Development," Journal of Regional Science, 50(4), 833-857.

de Blasio, Guido and Samuele Poy. 2013. "The Impact of Local Minimum Wages on Employment: Evidence from Italy in the 1950s," Bank of Italy Temi di Discussione No. 953. Rome: Bank of Italy.

Di Liberto, Adriana and Marco Sideri. 2015. "Past Dominations, Current Institutions and the Italian Regional Economic Performance," European Journal of Political Economy, 38, $12-41$.

Ermini, Filippo. 1893. Gli ordinamenti politici e amministrativi nelle "Constitutiones Aegidianae." Torino: Fratelli Bocca.

Felice, Emanuele. 2007. Divari regionali e intervento pubblico: per una rilettura dello sviluppo in Italia. Bologna: Il Mulino.

. 2011. "Regional Value Added in Italy, 1891-2001, and the Foundation of a Long-Term Picture," The Economic History Review, 64(3), 929-950.

- 2012. "Regional Convergence in Italy (1891-2001): Testing Human and Social Capital," Cliometrica, 6(3), 267-306.

2013. Perché il Sud è rimasto indietro. Bologna: Il Mulino.

Felice, Emanuele and Amedeo Lepore. 2013. "Le politiche di sviluppo nel Sud Italia rivisitate: storia d'impresa e conti regionali relativi all'intervento della «Cassa per il Mezzogiorno"," Rivista Economica del Mezzogiorno, 27(3), 593-634.

Felice, Emanuele and Michelangelo Vasta. 2015. "Passive Modernization? Social Indicators and Human Development in Italy's Regions (1871-2009)," European Review of Economic History, 19(1), 44-66.

Felice, Emanuele and Giovanni Vecchi. 2015. "Italy's Growth and Decline, 1861-2011," Journal of Interdisciplinary History, 45(4), 507-548.

Fisman, Raymond and Edward Miguel. 2007. "Corruption, Norms, and Legal Enforcement: Evidence from Diplomatic Parking Tickets," Journal of Political Economy, 115(6), 1020-1048.

Giordano, Raffaela and Pietro Tommasino. 2011. "Public sector efficiency and political culture," Temi di discussione (Economic working papers), Bank of Italy, Economic Research and International Relations Area 786. Rome: Bank of Italy.

Grosjean, Pauline. 2014. "A History of Violence: The Culture of Honor as a Determinant of Homicide in the US South," Journal of the European Economic Association, 12, 1285-1316.

Guiso, Luigi, Paola Sapienza, and Luigi Zingales 2008. "Long Term Persistence," National Bureau of Economic Research Working Paper Series No. 14278. Cambridge, MA: National Bureau of Economic Research.

International Bank for Reconstruction and Development. 1953. "Cassa per il Mezzogiorno. Summary and appraisal of activities until June 1953."

Lepore, Amedeo. 2011. "La valutazione dell'operato della Cassa per il Mezzogiorno, e il suo ruolo strategico per lo sviluppo del Paese," Rivista giuridica del Mezzogiorno, 1-2, 281-318.

. 2012a. "Cassa Per Il Mezzogiorno E Politiche Per Lo Sviluppo," SSRN Working Paper Series No. 1979896

. 2012b. "Dal Divario Nord-Sud alla Convergenza: il Modello dell'Intervento Straordinario e l'Azione della Cassa per il Mezzogiorno Durante e Oltre la Golden-Age," Pecvnia, 15, 79-107.

Nunn, Nathan. 2009. "The Importance of History for Economic Development," Annual Review of Economics, 1, 65-92.

Putnam, Robert, Robert Leonardi, and Raffaella Nanetti. 1993. Making Democracy Work: Civic Traditions in Modern Italy. Princeton, NJ: Princeton University Press.

SVIMEZ. 2001. "Il Mezzogiorno e la politica degli aiuti," in Riccardo Padovani, Franca Moro and Luca Bianchi (eds.), Informazioni SVIMEZ. Bologna: Il Mulino.

Tabellini, Guido. 2008. "The Scope of Cooperation: Values and Incentives," The Quarterly Journal of Economics, 123, 905-950.

Viesti, Gianfranco. 2003. Abolire il Mezzogiorno. Roma-Bar: Laterza.

\section{SUPPORTING INFORMATION}

Additional supporting information may be found in the online version of this article at the publisher's web site.

Table A1. List of municipalities within $50 \mathrm{~km}$ from Kingdom's border 